\title{
Nutrient utilisation and weathering inputs in the Peruvian upwelling region since the Little Ice Age
}

\author{
C. Ehlert ${ }^{1, *}$, P. Grasse ${ }^{1}$, D. Gutiérrez ${ }^{2}$, R. Salvatteci ${ }^{2,3}$, and M. Frank ${ }^{1}$ \\ ${ }^{1}$ GEOMAR Helmholtz Centre for Ocean Research Kiel, Kiel, Germany \\ ${ }^{2}$ Instituto del Mar del Perú (IMARPE), Dirección de Investigaciones Oceanográficas, Callao, Peru \\ ${ }^{3}$ Institute of Geoscience, Department of Geology, Kiel University, Ludewig-Meyn-Str. 10, 24118 Kiel, Germany \\ * now at: Max Planck Research Group for Marine Isotope Geochemistry, Institute for Chemistry and Biology of the Marine \\ Environment (ICBM), University of Oldenburg, Oldenburg, Germany \\ Correspondence to: C. Ehlert (cehlert@mpi-bremen.de)
}

Received: 16 July 2014 - Published in Clim. Past Discuss.: 20 August 2014

Revised: 17 November 2014 - Accepted: 12 January 2015 - Published: 10 February 2015

\begin{abstract}
For this study two sediment cores from the Peruvian shelf covering the time period between the Little Ice Age (LIA) and present were examined for changes in productivity (biogenic opal concentrations (bSi)), nutrient utilisation (stable isotope compositions of silicon $\left(\delta^{30} \mathrm{Si}_{\text {opal }}\right)$ and nitrogen $\left(\delta^{15} \mathrm{~N}_{\mathrm{sed}}\right)$ ), as well as in ocean circulation and material transport (authigenic and detrital radiogenic neodymium $\left(\varepsilon_{\mathrm{Nd}}\right)$ and strontium $\left({ }^{87} \mathrm{Sr} /{ }^{86} \mathrm{Sr}\right)$ isotopes $)$.

For the LIA the proxies recorded weak primary productivity and nutrient utilisation reflected by low average $\mathrm{bSi}$ concentrations of $\sim 10 \%, \delta^{15} \mathrm{~N}_{\text {sed }}$ values of $\sim 5 \%$ and intermediate $\delta^{30} \mathrm{Si}_{\text {opal }}$ values of $\sim 0.9 \%$. At the same time, the radiogenic isotope composition of the detrital sediment fraction indicates dominant local riverine input of lithogenic material due to higher rainfall in the Andean hinterland. These patterns were most likely caused by permanent El Niñolike conditions characterised by a deeper nutricline, weak upwelling and low nutrient supply. At the end of the LIA, $\delta^{30} \mathrm{Si}_{\text {opal }}$ dropped to low values of $+0.6 \%$ and opal productivity reached its minimum of the past 650 years. During the following transitional period of time the intensity of upwelling, nutrient supply and productivity increased abruptly as marked by the highest bSi contents of up to $38 \%$, by $\delta^{15} \mathrm{~N}_{\text {sed }}$ of up to $\sim 7 \%$, and by the highest degree of silicate utilisation with $\delta^{30} \mathrm{Si}_{\text {opal }}$ reaching values of $+1.1 \%$. At the same time, detrital $\varepsilon_{\mathrm{Nd}}$ and ${ }^{87} \mathrm{Sr} /{ }^{86} \mathrm{Sr}$ signatures documented increased wind strength and supply of dust to the shelf due to drier conditions. Since about 1870 , productivity has been high but nutrient utilisation has remained at levels
\end{abstract}

similar to the LIA, indicating significantly increased nutrient availability.

Comparison between the $\delta^{30} \mathrm{Si}_{\text {opal }}$ and $\delta^{15} \mathrm{~N}_{\text {sed }}$ signatures suggests that during the past 650 years the $\delta^{15} \mathrm{~N}_{\text {sed }}$ signature in the Peruvian upwelling area has to a large extent been controlled by surface water utilisation and not, as previously assumed, by subsurface nitrogen loss processes in the water column, which only had a significant influence during modern times (i.e. since $\sim$ AD 1870).

\section{Introduction}

Global climate of the late Holocene has been disrupted by major anomalies, the most recent of which being the Little Ice Age (LIA) between ca. AD 1400 and 1850 (Lamb, 1965; Grove, 2001). During that time a weakening of the Walker circulation (Conroy et al., 2008), a reduced influence of the South Pacific subtropical high (SPSH) along the Peruvian margin (Sifeddine et al., 2008; Gutiérrez et al., 2009; Salvatteci et al., 2014a), and a southward shift of the mean position of the Intertropical Convergence Zone (ITCZ) and the associated precipitation belt compared to today (Sachs et al., 2009) caused pronounced changes in rainfall patterns in the tropics. El Niño-like warmer conditions in the eastern South Pacific were accompanied by an intensified South American summer monsoon (Bird et al., 2011), resulting in $\sim 10 \%$ higher precipitation in northeastern Peru ( $\sim 5^{\circ} \mathrm{S}$; Rabatel et al., 2008) and up to $20-30 \%$ higher precipitation in the Bolivian Andes 
( $\sim 16^{\circ} \mathrm{S}$; Reuter et al., 2009). On the one hand this caused growth and extension of the Andean glaciers (Vuille et al., 2008) and on the other it enabled human settlements in the presently hyperarid southern Peruvian Andes (Unkel et al., 2007). In the upwelling areas off Peru and the western South American shelf regions, the main consequence of these climatic conditions during the LIA was a deepening of the nutricline and a strongly diminished biological productivity (Vargas et al., 2007; Sifeddine et al., 2008; Valdés et al., 2008; Gutiérrez et al., 2009).

Sediment cores from the Peruvian shelf covering the period of time from the LIA until present indicate that the marine realm was characterised by an abrupt biogeochemical regime shift towards modern conditions at the end of the LIA due to the northward movement of the ITCZ and an expansion of the SPSH. While low productivity and a more oxygenated water column prevailed during the LIA, markedly increased biological productivity and pronounced oxygen depletion over wide areas of the shelf have characterised the system since the end of the LIA (Vargas et al., 2007; Sifeddine et al., 2008; Gutiérrez et al., 2009; Salvatteci et al., 2014a).

In this study the stable silicon isotope composition of sedimentary diatoms $\left(\delta^{30} \mathrm{Si}_{\mathrm{opal}}\right)$ covering the period of time from the LIA to the present is analysed. The main goal is the reconstruction of the factors controlling the dynamics of nutrient cycling together with oxygen in the Peruvian upwelling, in particular a comparison between the $\delta^{30} \mathrm{Si}_{\text {opal }}$ and the stable nitrogen isotope composition $\left(\delta^{15} \mathrm{~N}_{\text {sed }}\right)$ of sedimentary organic matter. Both $\delta^{30} \mathrm{Si}_{\text {opal }}$ and $\delta^{15} \mathrm{~N}_{\text {sed }}$ provide information about utilisation of silicic acid $\left(\mathrm{Si}(\mathrm{OH})_{4}\right)$ and nitrate $\left(\mathrm{NO}_{3}^{-}\right)$during primary productivity, e.g. during the formation of diatom frustules and associated organic matter, respectively (Altabet and Francois, 1994; De La Rocha et al., 1997). Diatoms preferentially incorporate the lighter isotopes from the dissolved $\mathrm{Si}(\mathrm{OH})_{4}$ and $\mathrm{NO}_{3}^{-}$pools, leaving the residual dissolved nutrients enriched in the heavier isotopes (Wada and Hattori, 1978; Altabet et al., 1991; De La Rocha et al., 1997). Si isotope fractionation is mainly controlled by the utilisation of $\mathrm{Si}(\mathrm{OH})_{4}$ in surface waters by biota (diatoms) (e.g. De La Rocha et al., 1998; Brzezinski et al., 2002; Egan et al., 2012). The $\delta^{15} \mathrm{~N}$ of $\mathrm{NO}_{3}^{-}$is partly controlled by $\mathrm{NO}_{3}^{-}$ utilisation of marine organisms but is also affected by $\mathrm{N}$ loss processes in the water column (denitrification, anammox) (Codispoti et al., 2001; Dalsgaard et al., 2003), resulting in a marked enrichment of the upwelling source waters in the heavier ${ }^{15} \mathrm{NO}_{3}^{-}$(Liu and Kaplan, 1989; Lam et al., 2009; given that it is currently not possible to distinguish between different $\mathrm{N}$-loss processes from the sediments, we will use the term denitrification for simplicity). Consequently, sedimentary $\delta^{15} \mathrm{~N}_{\mathrm{sed}}$ records from areas dominated by oxygendepleted waters such as the shelf region off Peru are usually interpreted to directly reflect changes in the intensity of subsurface $\mathrm{NO}_{3}^{-}$loss and the extent and strength of oxygen depletion (e.g. De Pol-Holz et al., 2007, 2009; Agnihotri et al., 2008; Gutiérrez et al., 2009), whereas the effect of $\mathrm{NO}_{3}^{-}$ utilisation on the preserved $\delta^{15} \mathrm{~N}_{\mathrm{sed}}$ is often neglected. Comparison of both isotope systems can therefore provide information about the degree of utilisation of $\mathrm{NO}_{3}^{-}$and $\mathrm{Si}(\mathrm{OH})_{4}$ versus the influence of $\mathrm{NO}_{3}^{-}$loss processes. Increasing nutrient utilisation should result in a consistent increase in both $\delta^{30} \mathrm{Si}_{\text {opal }}$ and $\delta^{15} \mathrm{~N}_{\text {sed }}$. In contrast, a change in $\mathrm{NO}_{3}^{-}$reduction due to varying oxygen depletion in the water column would affect only the $\delta^{15} \mathrm{~N}_{\text {sed }}$, leaving the $\delta^{30} \mathrm{Si}_{\text {opal }}$ unaffected.

The main forces driving surface productivity and subsurface oxygenation off Peru at centennial timescales during the past two millennia have been changes in the strength of the Walker circulation and in the expansion/contraction of the SPSH (Gutierrez et al., 2009; Salvatteci et al., 2014a). Therefore, the radiogenic isotope compositions of neodymium $\left(\varepsilon_{\mathrm{Nd}}\right)$ and strontium $\left({ }^{87} \mathrm{Sr} /{ }^{86} \mathrm{Sr}\right)$ of the authigenic ferromanganese (Fe-Mn) oxyhydroxide coatings of the sedimentary particles, which are expected to record the radiogenic isotope compositions of past bottom waters, as well as of the detrital fraction of the sediment were examined. These proxy data provide information about changes in (surface ocean) circulation and transport processes, provenance of the sediments, and input mechanisms of terrigenous material as a function of changes in precipitation on land during the transition from wetter LIA conditions to drier modern conditions. Weathering of continental source rocks delivers lithogenic particles of different origin and age to the shelf, which have distinct radiogenic isotope signatures $\left(\varepsilon_{\mathrm{Nd} \text { detritus }},{ }^{87} \mathrm{Sr} /{ }^{86} \mathrm{Sr}_{\text {detritus }}\right)$ that can be used to trace their source areas (Goldstein et al., 1984). Central Peruvian Andean rocks have more radiogenic $\varepsilon_{\mathrm{Nd}}$ signatures whereas southern Peruvian rocks are characterised by less radiogenic $\varepsilon_{\mathrm{Nd}}$ signatures (Sarbas and Nohl, 2009), which is also reflected in the sediments along the shelf (Ehlert et al., 2013). Changes in detrital material input and transport pathways are generally closely related to climatic changes causing variations in the supply from the respective source areas (e.g. Grousset et al., 1988). It should therefore be possible to detect the transition from wetter LIA conditions with higher local input from central Peru via rivers due to higher precipitation rates towards the drier presently prevailing conditions with an increased influence of aeolian material transport from further south in the Atacama Desert (Molina-Cruz, 1977) and deposition along the shelf after the LIA.

\section{Material and methods}

\subsection{Core locations and age models}

For the reconstruction of surface water $\mathrm{Si}(\mathrm{OH})_{4}$ utilisation and terrestrial material input and transport for the period of time between the LIA and present, two sediment cores with high sedimentation rates were analysed. Box core B0405-6 was recovered from the upper continental slope off Pisco at 


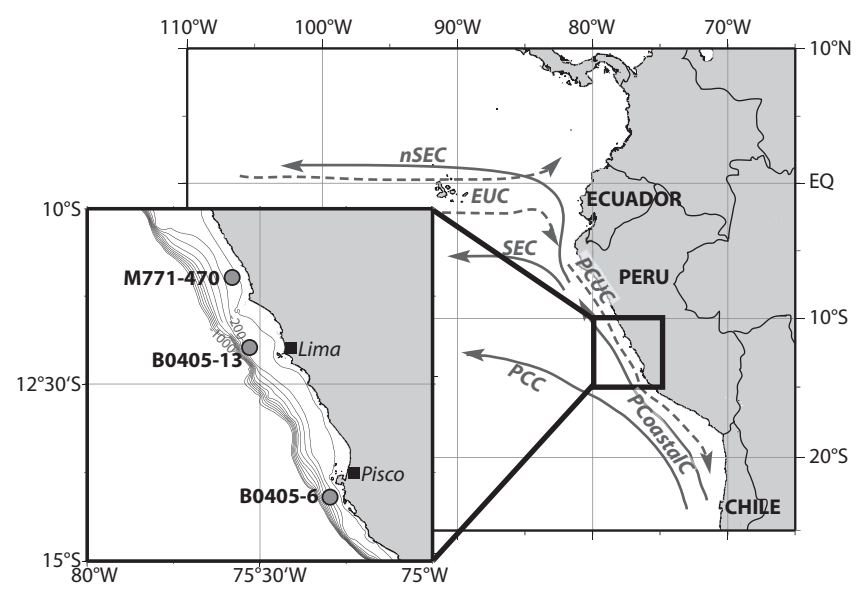

Figure 1. Schematic circulation patterns in the eastern equatorial Pacific. Surface currents (solid lines): (n)SEC, (northern) South Equatorial Current; PCC, Peru-Chile Current; PCoastalC, Peru Coastal Current. Subsurface currents (dashed lines): EUC, Equatorial Undercurrent; PCUC, Peru-Chile Undercurrent (after Brink, 1983; Kessler, 2006). The inset shows the location of cores M771470, B0405-6 and B0405-13 (grey dots) in greater detail. The bathymetry is given for 0 to $1000 \mathrm{~m}$ water depth in $100 \mathrm{~m}$ increments.

$14^{\circ} 07.9^{\prime} \mathrm{S}, 76^{\circ} 30.1^{\prime} \mathrm{W}$ at a water depth of $299 \mathrm{~m}$ with the Peruvian RV José Olaya Balandra in 2004 (Fig. 1) (Gutiérrez et al., 2006). The age model was previously published by Gutiérrez et al. (2009) and is based on downcore profiling of the activities of ${ }^{241} \mathrm{Am}$, excess ${ }^{210} \mathrm{~Pb}$, and on radiocarbon ages obtained from bulk sedimentary organic carbon, which document that the core covers the past $\sim 650$ years. The second core, multicorer M771-470, was taken at $11^{\circ} \mathrm{S}, 77^{\circ} 56.6^{\prime} \mathrm{W}$ at $145 \mathrm{~m}$ water depth during cruise M77/1 with the German RV Meteor in 2008 (Fig. 1). The age model was obtained by measuring excess ${ }^{210} \mathrm{~Pb}$ activities and modelling of the resulting profiles as described by Meysman et al. (2005) (for details see Supplement). Ages prior to $\sim \mathrm{AD} 1850$ were inferred using sedimentation rates from nearby core B0405-13 (Gutiérrez et al., 2009; Salvatteci et al., 2014b).

\subsection{Methods}

\subsubsection{Biogenic opal and silicon isotope analyses}

The biogenic opal (bSi) contents in both cores were measured following the sequential leaching techniques described by DeMaster (1981) and Müller and Schneider (1993). Si isotope analyses were performed on the 11-32 $\mu \mathrm{m}$ diatom fraction that was extracted from the sediment applying the procedures described by Morley et al. (2004).

Approximately $300 \mathrm{mg}$ of sediment was treated with $30 \%$ $\mathrm{H}_{2} \mathrm{O}_{2}$ and $35 \% \mathrm{HCl}$ to remove organic matter and carbonate. Afterwards the sediment was wet-sieved to separate the
11-32 $\mu \mathrm{m}$ fraction. In a third step a heavy-liquid solution (sodium polytungstate, $2.1-2.2 \mathrm{~g} \mathrm{~mL}^{-1}$ ) was applied in several steps to separate diatoms from the detrital lithogenic silicate material. All samples were screened under the microscope to verify their purity with respect to the detrital (clay) fraction.

The diatom samples were then transferred into Teflon vials and dissolved in $1 \mathrm{~mL}$ of $0.1 \mathrm{M} \mathrm{NaOH}$ and diluted with Milli-Q water according to Reynolds et al. (2008). More details are provided in Ehlert et al. (2012). Si concentrations of the dissolved diatom samples were measured colorimetrically using a photospectrometer (Hansen and Koroleff, 1999). Chromatographic separation and purification of the $\mathrm{Si}$ was achieved with $1 \mathrm{~mL}$ pre-cleaned AG50W-X8 cation exchange resin (mesh 200-400) (Georg et al., 2006; as modified by de Souza et al., 2012). Si isotope ratios were measured on a $\mathrm{Nu}$ Plasma HR MC-ICPMS (Nu Instruments) at GEOMAR equipped with an adjustable source-defining slit, which can be set to medium resolution to ensure separation of the ${ }^{30} \mathrm{Si}$ peak from molecular interferences. The measurements were carried out applying standard-sample bracketing (Albarède et al., 2004). All solutions were measured at a Si concentration of $14-21 \mu \mathrm{mol} \mathrm{kg}{ }^{-1}$ of samples and standards depending on the performance of the instrument on the respective measurement day and were introduced into the plasma via a Cetac Aridus II desolvating nebuliser system equipped with a PFA nebuliser operated at a 60 to $80 \mu \mathrm{L} \mathrm{min}^{-1}$ uptake rate. Si isotope compositions are reported in the $\delta^{30} \mathrm{Si}$ notation as deviations of the measured ${ }^{30} \mathrm{Si} /{ }^{28} \mathrm{Si}$ from the NIST standard NBS28 in parts per thousand $(\% \circ)$. Repeated measurements of the reference materials IRMM018 and Big Batch gave average ${ }^{30} \mathrm{Si}$ values of $-1.52 \pm 0.18 \%$ o $\left(2 \sigma_{(\mathrm{sd})}\right)$ and $-10.84 \pm 0.18 \%$ o $\left(2 \sigma_{(\mathrm{sd})}\right)$, respectively, which are in good agreement with values obtained by other laboratories (Reynolds et al., 2007). Samples were measured three to five times within a 1-day session and measurements were repeated on at least 2 separate days. The resulting uncertainties ranged between 0.04 and $0.23 \%$ o $\left(2 \sigma_{(\mathrm{sd})}\right)$ (Tables 1,2). Replicate measurements of an in-house diatom matrix standard over longer periods of time gave an external reproducibility of $0.11 \% \circ\left(2 \sigma_{(\mathrm{sd})}\right)$. Error bars provided in the figures correspond to that external reproducibility unless the uncertainties of the repeated sample measurements were higher.

\subsubsection{Neodymium and strontium isotope analyses}

To obtain the radiogenic isotope composition of past bottom seawater at the sites of the sediment cores from the early diagenetic Fe-Mn coatings of the sediment particles, previously published methods were applied (Gutjahr et al., 2007; see Supplement for details). The residual detrital material was leached repeatedly to remove remaining coatings and was then treated with a mixture of concentrated $\mathrm{HF}-\mathrm{HNO}_{3}-\mathrm{HCl}$ for total dissolution. The separation and purification of $\mathrm{Nd}$ 
Table 1. Downcore records of core M771-470 for $\delta^{30} \mathrm{Si}_{\text {opal }}\left(\%\right.$ o); bSi content (wt \%); and ${ }^{143} \mathrm{Nd} /{ }^{144} \mathrm{Nd}, \varepsilon_{\mathrm{Nd}}$ and ${ }^{87} \mathrm{Sr} /{ }^{86} \mathrm{Sr}$ of detrital material. $2 \sigma_{(\mathrm{sd})}$ represents the external reproducibilities of repeated sample $(\mathrm{Si})$ and standard $(\mathrm{Nd}, \mathrm{Sr})$ measurements.

\begin{tabular}{lcccccccc}
\hline $\begin{array}{l}\text { Depth } \\
(\mathrm{cm})\end{array}$ & $\begin{array}{c}{ }^{30} \mathrm{Si}_{\text {opal }} \\
(\%)\end{array}$ & $2 \sigma_{(\mathrm{sd})}$ & $\begin{array}{c}\mathrm{bSi} \\
(\mathrm{wt} \%)\end{array}$ & ${ }^{143} \mathrm{Nd} /{ }^{144} \mathrm{Nd}_{\text {detritus }}$ & $\varepsilon_{\mathrm{Nd} \text { detritus }}$ & $2 \sigma_{(\mathrm{sd})}$ & ${ }^{87} \mathrm{Sr} /{ }^{86} \mathrm{Sr}_{\text {detritus }}$ & $2 \sigma_{(\mathrm{sd})}$ \\
\hline 0.5 & 1.03 & 0.15 & 18.8 & - & - & - & - & - \\
1.5 & - & - & 18.6 & - & - & - & - & - \\
2.5 & - & - & 22.2 & - & - & - & - & - \\
3.5 & 0.93 & 0.08 & 16.9 & 0.512369 & -5.2 & 0.3 & 0.709315 & $1.5 \mathrm{e}-05$ \\
4.5 & - & - & 16.3 & - & - & - & - & - \\
5.5 & - & - & 17.2 & 0.512381 & -5.0 & 0.3 & 0.709356 & $1.5 \mathrm{e}-05$ \\
7 & - & - & 19.5 & - & - & - & - & - \\
9 & 0.96 & 0.09 & 19.8 & 0.512398 & -4.7 & 0.3 & 0.708822 & $1.5 \mathrm{e}-05$ \\
11 & - & - & 18.8 & - & - & - & - & - \\
13 & - & - & 15.9 & - & - & - & - & - \\
15 & - & - & - & 0.512383 & -5.0 & 0.3 & 0.708737 & $1.5 \mathrm{e}-05$ \\
16 & 0.96 & 0.07 & 19.3 & - & - & - & - & - \\
19 & - & - & - & 0.512386 & -4.9 & 0.3 & 0.708552 & $1.5 \mathrm{e}-05$ \\
20 & 1.05 & 0.10 & 18.9 & 0.512410 & -4.5 & 0.3 & 0.708412 & $8.0 \mathrm{e}-06$ \\
23 & - & - & - & 0.512393 & -4.8 & 0.3 & 0.708720 & $1.5 \mathrm{e}-05$ \\
24 & 1.15 & 0.13 & 26.9 & - & - & - & - & - \\
26 & - & - & - & 0.512387 & -4.9 & 0.3 & 0.707482 & $8.0 \mathrm{e}-06$ \\
27 & - & - & - & 0.512397 & -4.7 & 0.3 & 0.707555 & $1.5 \mathrm{e}-05$ \\
28 & 1.00 & 0.14 & 14.0 & - & - & - & - & - \\
29 & - & - & - & 0.512452 & -3.6 & 0.3 & 0.706549 & $1.5 \mathrm{e}-05$ \\
32 & 0.55 & 0.17 & 10.1 & 0.512442 & -3.8 & 0.3 & 0.706763 & $1.5 \mathrm{e}-05$ \\
32 & - & - & - & 0.512445 & -3.8 & 0.3 & 0.706469 & $8.0 \mathrm{e}-06$ \\
36 & 1.10 & 0.15 & 14.4 & 0.512419 & -4.3 & 0.3 & 0.706767 & $8.0 \mathrm{e}-06$ \\
40 & 0.79 & 0.11 & 12.3 & 0.512408 & -4.5 & 0.3 & 0.706964 & $8.0 \mathrm{e}-06$ \\
44 & 0.91 & 0.18 & 15.0 & 0.512421 & -4.2 & 0.3 & 0.707057 & $8.0 \mathrm{e}-06$ \\
48 & 0.75 & 0.05 & - & 0.512395 & -4.7 & 0.3 & 0.707816 & $8.0 \mathrm{e}-06$ \\
\hline
\end{tabular}

Table 2. Downcore records of core B0405-6 for $\delta^{30} \mathrm{Si}_{\text {opal }}\left(\%\right.$ ); bSi content (wt \%); and ${ }^{143} \mathrm{Nd} /{ }^{144} \mathrm{Nd}, \varepsilon_{\mathrm{Nd}}$ and ${ }^{87} \mathrm{Sr} /{ }^{86} \mathrm{Sr}$ of detrital material. $2 \sigma_{(\mathrm{sd})}$ represents the external reproducibilities of repeated sample $(\mathrm{Si})$ and standard $(\mathrm{Nd}, \mathrm{Sr})$ measurements.

\begin{tabular}{lcccccccc}
\hline Year AD & $\begin{array}{c}{ }^{30} \mathrm{Si}_{\text {opal }} \\
(\%)\end{array}$ & $2 \sigma_{(\mathrm{sd})}$ & $\begin{array}{c}\mathrm{bSi} \\
(\mathrm{wt} \%)\end{array}$ & ${ }^{143} \mathrm{Nd} /{ }^{144} \mathrm{Nd}_{\text {detritus }}$ & $\varepsilon_{\mathrm{Nd} \text { detritus }}$ & $2 \sigma_{(\mathrm{sd})}$ & ${ }^{87} \mathrm{Sr} /{ }^{86} \mathrm{Sr}_{\text {detritus }}$ & $2 \sigma_{(\mathrm{sd})}$ \\
\hline 1950 & 0.91 & 0.15 & 21.7 & 0.512507 & -2.6 & 0.1 & 0.708372 & $8.0 \mathrm{e}-06$ \\
1925 & 0.83 & 0.15 & 21.0 & 0.512460 & -3.5 & 0.3 & 0.707923 & $8.0 \mathrm{e}-06$ \\
1903 & 0.62 & 0.10 & 18.9 & 0.512487 & -2.9 & 0.3 & 0.707715 & $8.0 \mathrm{e}-06$ \\
1857 & 1.02 & 0.16 & 34.4 & 0.512471 & -3.3 & 0.3 & 0.707829 & $8.0 \mathrm{e}-06$ \\
1857 & 1.22 & 0.14 & 37.7 & 0.512481 & -3.1 & 0.1 & 0.707736 & $8.0 \mathrm{e}-06$ \\
1818 & 0.56 & 0.15 & 12.6 & 0.512468 & -3.3 & 0.3 & 0.707702 & $8.0 \mathrm{e}-06$ \\
1793 & 0.82 & 0.14 & 15.8 & 0.512446 & -3.7 & 0.3 & 0.707265 & $8.0 \mathrm{e}-06$ \\
1761 & 0.71 & 0.16 & 13.5 & 0.512627 & -0.2 & 0.3 & 0.707296 & $8.0 \mathrm{e}-06$ \\
1698 & 0.73 & 0.09 & 17.3 & 0.512462 & -3.4 & 0.3 & 0.707278 & $8.0 \mathrm{e}-06$ \\
1564 & 0.81 & 0.12 & 20.8 & 0.512467 & -3.3 & 0.3 & 0.707281 & $8.0 \mathrm{e}-06$ \\
1475 & 0.77 & 0.04 & 17.1 & 0.512427 & -4.1 & 0.3 & 0.707959 & $8.0 \mathrm{e}-06$ \\
1370 & 0.80 & 0.23 & 34.2 & 0.512509 & -2.5 & 0.3 & 0.707111 & $8.0 \mathrm{e}-06$ \\
\hline
\end{tabular}




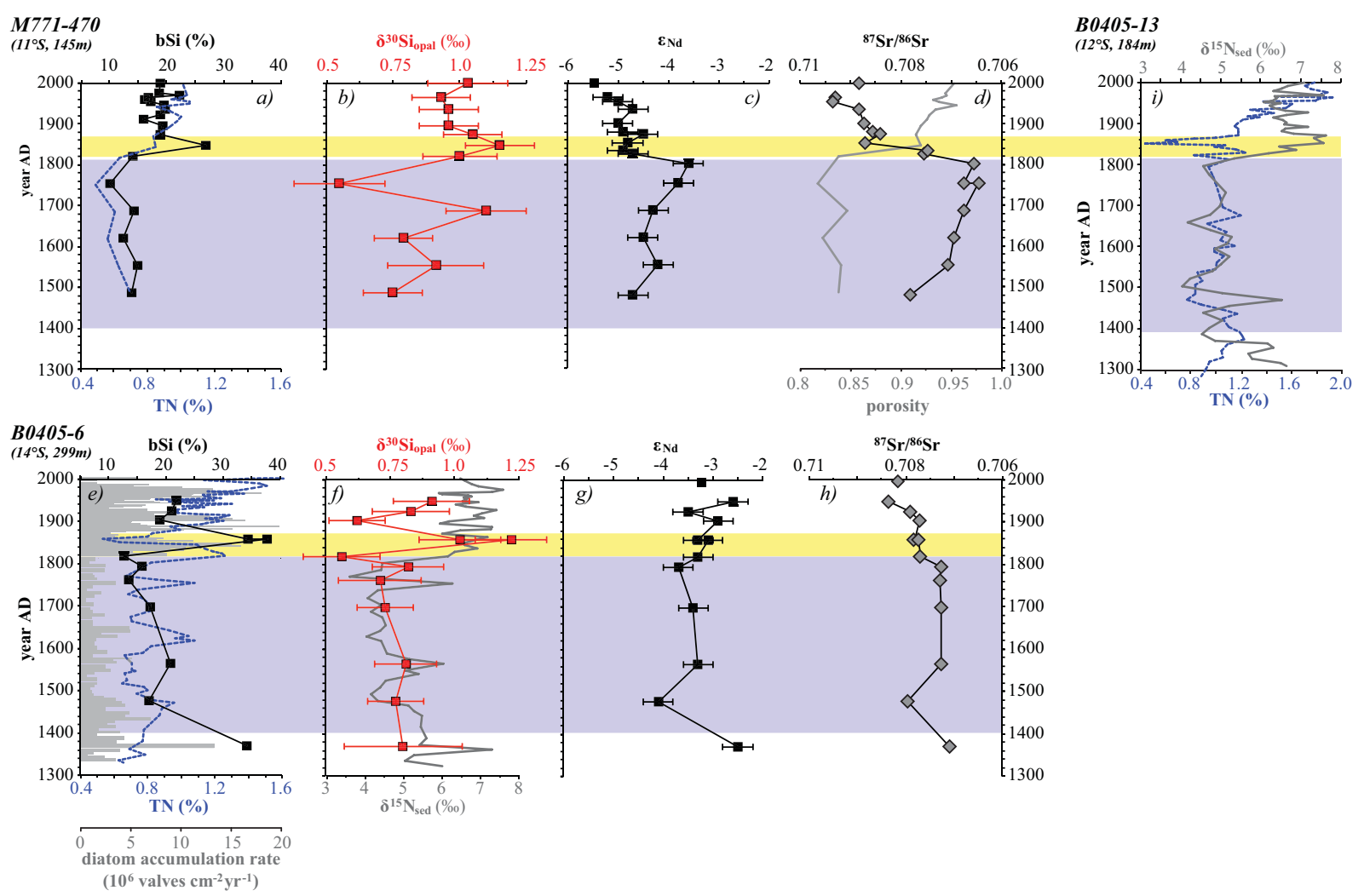

Figure 2. Downcore records for core M771-470 (upper panel) and core B0405-6 (lower panel). The blue and yellow shadings indicate the age range of the LIA and the transitional period, respectively. (a, e) bSi concentration (black squares), (a, e, i) total $\mathrm{N}$ concentration (dashed blue curve), (e) diatom accumulation rate (grey bars) (Gutiérrez et al., 2009), (b, f) $\delta^{30} \mathrm{Si}_{\text {opal }}$ (red squares), (f) bulk $\delta^{15} \mathrm{~N}_{\text {sed }}$ (grey curve)

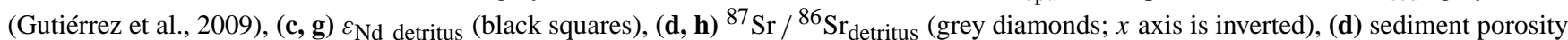
(grey curve). Error bars represent $2 \sigma_{(\mathrm{sd})}$ external reproducibilities of repeated standard or sample measurements. For comparison, (i) shows the total $\mathrm{N}$ content and $\delta^{15} \mathrm{~N}_{\text {sed }}$ of core B0405-13 (Gutiérrez et al., 2009).

and $\mathrm{Sr}$ in the leachates and in the completely dissolved detrital sediment fraction followed previously published procedures for $\mathrm{Nd}$ (Cohen et al., 1988) and $\mathrm{Sr}$ (Horwitz et al., 1992) applying ion exchange chromatography for separation of $\mathrm{Rb} / \mathrm{Sr}$ from the rare earth elements (REEs) $(0.8 \mathrm{~mL}$ AG50W-X12 resin, mesh 200-400) followed by separation of $\mathrm{Sr}$ from $\mathrm{Rb}(50 \mu \mathrm{L}$ Sr-Spec resin, mesh 50-100), and separation of $\mathrm{Nd}$ from the other REEs $(2 \mathrm{~mL}$ Eichrom LnSpec resin, mesh 50-100). All radiogenic isotope measurements were performed on the Nu Plasma HR MC-ICPMS (Nu Instruments) at GEOMAR. Measured Nd isotope compositions were corrected for instrumental mass bias using a ${ }^{146} \mathrm{Nd} /{ }^{144} \mathrm{Nd}$ ratio of 0.7219 and were normalised to the accepted ${ }^{143} \mathrm{Nd} /{ }^{144} \mathrm{Nd}$ literature value of 0.512115 of the JNdi-1 standard (Tanaka et al., 2000). All values are given as $\varepsilon_{\mathrm{Nd}}$, which corresponds to the measured ${ }^{143} \mathrm{Nd} /{ }^{144} \mathrm{Nd}$, normalised to the chondritic uniform reservoir (CHUR) (0.512638), multiplied by 10000 . The external reproducibility was estimated via repeated measurements of the JNdi-1 standard and was always better than $20 \mathrm{ppm}\left(2 \sigma_{(\mathrm{sd})}\right.$, Tables 1 , 2). Measured ${ }^{87} \mathrm{Sr} /{ }^{86} \mathrm{Sr}$ ratios were corrected for instrumen- tal mass bias using ${ }^{88} \mathrm{Sr} /{ }^{86} \mathrm{Sr}=8.3752$ and were normalised to the accepted value for NIST SRM987 of 0.710245 . The $2 \sigma_{(\mathrm{sd})}$ external reproducibility of repeated standard measurements was always better than $36 \mathrm{ppm}\left(2 \sigma_{(\mathrm{sd})}\right.$, Tables 1,2$)$. Procedural Nd and Sr blanks for leachates and total dissolutions of the detrital material were $\leq 83 \mathrm{pg}$ and $2.1 \mathrm{ng}$, respectively, and thus negligible compared to the concentrations of the samples.

\section{Results}

\subsection{Core M771-470 (Callao)}

Sediment core M771-470, from a location at $11^{\circ} \mathrm{S} 145 \mathrm{~m}$ water depth, is characterised by bSi concentrations between 10.1 and $26.9 \%$ and total $\mathrm{N}$ contents between 0.5 and $1.1 \%$ (Fig. 2a, Table 1), whereby the lowest values occurred just prior to the end of the LIA. The maximum bSi concentrations were found during the transition period. In contrast, the highest nitrogen $(\mathrm{N})$ content occurred later in the youngest part of the record. The $\delta^{30} \mathrm{Si}_{\text {opal }}$ varied between +0.6 and 
$+1.1 \%$ (Fig. 2b) and followed bSi concentrations with the maximum and minimum isotope values corresponding to the same respective depths for both parameters.

The $\varepsilon_{\text {Nd detritus }}$ is characterised by values between -3.6 and -5.2 , with a mean value of $-4.5 \pm 1.0\left(2 \sigma_{(\mathrm{sd})}\right)$ (Fig. $2 \mathrm{c}$, Table 1). The ${ }^{87} \mathrm{Sr} /{ }^{86} \mathrm{Sr}_{\text {detritus }}$ signatures of the same samples range between 0.70647 and 0.70936 (Fig. 2d, Table 1). The variability of $\varepsilon_{\mathrm{Nd}}$ detritus and ${ }^{87} \mathrm{Sr} /{ }^{86} \mathrm{Sr}_{\text {detritus }}$ is very similar. Samples from the LIA show a trend towards more radiogenic $\varepsilon_{\mathrm{Nd}}$ detritus and less radiogenic ${ }^{87} \mathrm{Sr} /{ }^{86} \mathrm{Sr}_{\text {detritus }}$. At the beginning of the transition period, both records indicate a marked change to less radiogenic $\varepsilon_{\mathrm{Nd}}$ detritus and more radiogenic ${ }^{87} \mathrm{Sr} /{ }^{86} \mathrm{Sr}_{\text {detritus }}$ values, which was more pronounced in the $\mathrm{Sr}$ than in the $\mathrm{Nd}$ isotope data, resulting in the youngest samples having the least radiogenic $\varepsilon_{\mathrm{Nd}}$ detritus and the most radiogenic ${ }^{87} \mathrm{Sr} /{ }^{86} \mathrm{Sr}_{\text {detritus }}$ signatures.

In theory, the radiogenic isotope composition of authigenic Fe-Mn oxyhydroxide coatings is a useful tracer to detect changes on the prevailing bottom water masses at a distinct location. The Peru-Chile Undercurrent (PCUC), which dominates the bottom waters at the core locations today, is characterised by radiogenic $\varepsilon_{\mathrm{Nd}}$ signatures of -1.8 (Lacan and Jeandel, 2001; Grasse et al., 2012). A deepening of the nutricline and a vertical expansion of surface water masses during the LIA could change that value towards less radiogenic signatures typical for water masses originating from the South Pacific (Piepgras and Wasserburg, 1982; Grasse et al., 2012). However, as has been shown before (Ehlert et al., 2013), the authigenic coating fraction from sediments along the Peruvian shelf does not necessarily represent changes in water mass advection and is therefore not a reliable proxy (see also Supplement for details).

\subsection{Core B0405-6 (Pisco)}

In core B0405-6, from a location near $14^{\circ} \mathrm{S}$ off Pisco at $299 \mathrm{~m}$ water depth, the range of bSi concentrations and its maximum value are higher than in core M771-470 and varied between 12.6 and $37.7 \%$ (Fig. 2e, Table 2). The trends are very similar to those of core M771-470, and bSi content correlates closely with the diatom accumulation rate (Fig. 2e). The lowest values of both parameters occurred at the end of the LIA and highest values were found right after the end of the LIA at the beginning of the transition period. The $\mathrm{N}$ content ranges from $0.5 \%$ around $\mathrm{AD} 1860$ to $1.8 \%$ in the youngest sample of the record (Fig. 2e) (Gutiérrez et al., 2009) with maximum $\mathrm{N}$ content in core B0405-6 also being higher than in core M771-470. The $\delta^{30} \mathrm{Si}_{\text {opal }}$ record shows the same range from +0.6 to $+1.1 \% o$ as core M771-470 and a very similar trend with the lowest values near the end of the LIA and the highest values immediately thereafter during the transition period (Fig. 2f, Table 3). The $\delta^{15} \mathrm{~N}_{\text {sed }}$ ranges between 3.6 and $7.6 \%$ and shows a trend from lower mean values around 4 to $5 \%$ o during the LIA to higher values between 6 and $7 \%$ in the modern sediments (Fig. 2f).
The $\varepsilon_{\mathrm{Nd}}$ detritus signatures are characterised by overall somewhat more radiogenic values than of core M771-470 ranging from -4.1 to -2.5 (mean value $-3.2 \pm 0.9,2 \sigma_{(\mathrm{sd})}$ excluding the value of $-0.2 \varepsilon_{\mathrm{Nd}}$ at $\mathrm{AD} 1761$, which is considered an outlier), with slightly less radiogenic values in the older part of the record and more radiogenic values in the younger part (Fig. 2g, Table 2). The ${ }^{87} \mathrm{Sr} /{ }^{86} \mathrm{Sr}_{\text {detritus }}$ values range between 0.70711 and 0.70796 (Fig. 2h, Table 2). Similar to core M771-470, although less pronounced, the main feature in the detrital $\mathrm{Sr}$ isotope record observed is a trend from less radiogenic ${ }^{87} \mathrm{Sr} /{ }^{86} \mathrm{Sr}_{\text {detritus }}$ values in the older part of the record towards more radiogenic values in the youngest part, with a shift at the end of the LIA and during the early transition period.

\section{Discussion}

After the end of the LIA, around AD 1820, the mean position of the ITCZ shifted northward (Sachs et al., 2009), causing an intensification of alongshore winds and enhanced coastal upwelling off the Peruvian coast (Sifeddine et al., 2008; Gutiérrez et al., 2009), diminished coastal sea surface temperatures (Vargas et al., 2007), and a decrease in precipitation on land (Rabatel et al., 2008; Bird et al., 2011). Records of productivity and redox conditions based on $\delta^{15} \mathrm{~N}_{\text {sed }}$ and the Mo and $\mathrm{Cd}$ content of the sediments indicate a rapid change in the biogeochemical composition of the source waters to higher nutrient concentrations, causing higher biological productivity and lower subsurface oxygen, which have persisted until the present day (Sifeddine et al., 2008; Gutiérrez et al., 2009; Salvatteci et al., 2014a). The shift after the end of the LIA constitutes a major anomaly of late Holocene climate in the eastern Pacific, which was of the same order of magnitude as the changes in conditions off Chile during the Younger Dryas (De Pol-Holz et al., 2006). This study focuses on the reconstruction of the regime shift from the LIA and a transitional period towards modern conditions and its controlling factors, including the evolution of nutrient utilisation and changes in the advection of water masses and material transport.

\subsection{Changes in biological productivity and nutrient consumption}

\subsubsection{Evolution of surface water productivity and nutrient utilisation}

The pronounced change in the biogeochemical regime from low productivity during the LIA to higher productivity during the transitional and modern period thereafter is documented by several sedimentary records from the eastern equatorial Pacific (EEP) region and has been dated at $\sim \mathrm{AD} 1820$ (Sifeddine et al., 2008; Gutierrez et al., 2009; Díaz-Ochoa et al., 2009, 2011; Salvatteci et al., 2014a). Similarly, both cores M771-470 from $11^{\circ} \mathrm{S}$ and B0405-6 from $14^{\circ} \mathrm{S}$ off 
Pisco show the characteristic coeval pronounced increase in bSi and total $\mathrm{N}$ content (Fig. 2a, e) and $\mathrm{C}_{\text {org }}$ concentration (not shown here) after the end of the LIA and during the transition period. Therefore, three time periods that show distinct differences in productivity and nutrient utilisation have been identified from our records and will be discussed in the following: the LIA, the transition period from the LIA to modern conditions between $\sim 1820$ and $\sim$ AD 1870, and modern conditions after $\sim$ AD 1870 .

Both cores recorded a 2- to 3-fold increase in bSi content from 10 to $12 \%$ prior to the end of the LIA to values of up to $27 \%$ in M771-470 and up to $38 \%$ in B0405-6 during the transition period (Fig. 2a, e). Afterwards the bSi contents decreased again but since then have remained at a level of $\sim 20 \%$ since then and are thus significantly higher than prior to the end of the LIA. The increase in bSi content is also reflected by a marked increase in diatom accumulation rate in core B0405-6 (Fig. 2e) (Gutiérrez et al., 2009). Analyses of the downcore diatom assemblages have shown that the high diatom accumulation rates and bSi content in core B04056 during the transition period were associated with diatom layers dominated by Skeletonema costatum (Gutiérrez et al., 2009), a species that is today more abundant when upwelling is more intense during austral winter/spring.

Both cores are characterised by a very high correlation between total $\mathrm{N}$ and $\mathrm{C}_{\text {org }}$ content $\left(r^{2}=0.95\right.$ for core $\mathrm{M} 771-470$ and 0.8 for core B0405-6) (Gutiérrez et al., 2009, 2015). In contrast, bSi and total $\mathrm{N}$ contents do not co-vary throughout the records (Fig. 3a). Surface sediments from the Peruvian shelf region between the Equator and $\sim 18^{\circ} \mathrm{S}$ show a relatively weak but positive correlation between bSi and $\mathrm{N}$ contents $\left(r^{2}=0.5\right.$, Fig. 3a) (Ehlert et al., 2012; Mollier-Vogel et al., 2012). Similar to the surface sediments, bSi and total $\mathrm{N}$ concentrations in core M771-470 are positively correlated, whereas they essentially do not correlate in core B0405-6. This is because the bSi maximum at the end of the transition period was more pronounced in core B0405-6 and higher than surface sediment bSi contents anywhere along the shelf region off Peru. At the same time, only a rather gradual increase in total $\mathrm{N}$ content occurred, with some excursions to low values during the transition period (Fig. 2a, e). The total $\mathrm{N}$ concentration also did not always co-vary with $\delta^{15} \mathrm{~N}_{\text {sed }}$ (Fig. 3c). In particular, the samples from the late transition period show very low total $\mathrm{N}$ concentrations but high $\delta^{15} \mathrm{~N}_{\text {sed }}$ and high $\delta^{30} \mathrm{Si}_{\text {opal }}$ and bSi content.

Sedimentary $\delta^{15} \mathrm{~N}_{\text {sed }}$ data, which are only available for core B0405-6, show a shift from lower values around +4 to $+5 \%$ o during the LIA to higher values around $+7 \%$ after the end of the LIA and have remained at that level since then (Fig. 2f) (Gutiérrez et al., 2009). The values in the younger part of the record are in good agreement with surface sediment $\delta^{15} \mathrm{~N}_{\text {sed }}$ data measured in the main Peruvian upwelling region ranging from +6 to $+9 \%$ (Mollier-Vogel et al., 2012). Bulk $\delta^{15} \mathrm{~N}_{\text {sed }}$ signatures measured in core B040513 from $12^{\circ} \mathrm{S}$ (184 $\mathrm{m}$ water depth) close to the location of core M771-470 can be used for comparison and show very similar values, amplitude, and variability to core B0405-6 (Fig. 2i) (Gutiérrez et al., 2009). In contrast to $\delta^{15} \mathrm{~N}_{\text {sed }}$, the $\delta^{30} \mathrm{Si}_{\text {opal }}$ signatures, which mainly reflect changes in surface water nutrient utilisation, are not only characterised by a simple increase at the end of the LIA. Instead, both $\delta^{30} \mathrm{Si}_{\text {opal }}$ records closely follow the evolution of the bSi concentrations and show intermediate $\delta^{30} \mathrm{Si}_{\text {opal }}$ signatures between +0.8 and $+0.9 \%$ o during the LIA; a pronounced short-term decrease to $+0.6 \%$ at the end of the LIA, which was followed by a marked increase to values around $+1.1 \%$ during the transition period; and finally a return to intermediate values between +0.8 and $+1.0 \%$ in the modern part of the records (Fig. 2b, f). The correspondence between bSi content and $\delta^{30} \mathrm{Si}_{\text {opal }}$ is more pronounced in core B0405-6 (Fig. 3b), which shows a higher variability and amplitude of bSi content. The difference in the $\delta^{30} \mathrm{Si}_{\text {opal }}, \delta^{15} \mathrm{~N}_{\text {sed }}, \mathrm{bSi}$ and total $\mathrm{N}$ content records during the transition from LIA to modern conditions reflects the different environmental factors controlling the proxies, which will be discussed in the following sections.

\subsubsection{Present-day surface water utilisation versus subsurface nitrate loss}

Diatoms are the dominant phytoplankton group of the Peruvian upwelling region (Estrada and Blasco, 1985; Bruland et al., 2005). The $\delta^{30} \mathrm{Si}_{\text {opal }}$ of these diatoms is primarily controlled by surface water diatom productivity and $\mathrm{Si}(\mathrm{OH})_{4}$ utilisation (De La Rocha et al., 1998; Brzezinski et al., 2002; Egan et al., 2012). Off Peru the $\delta^{30} \mathrm{Si}_{\text {opal }}$ has also been shown to be dependent on the isotopic signature of the advected surface and subsurface water masses (Ehlert et al., 2012; Grasse et al., 2013). Similarly, the $\delta^{15} \mathrm{~N}_{\text {sed }}$ of the organic matter is controlled by $\mathrm{N}$ isotope fractionation during $\mathrm{NO}_{3}^{-}$uptake by phytoplankton, mostly diatoms. Off Peru, however, the $\mathrm{NO}_{3}^{-}$ supplied to the surface waters has previously been enriched in ${ }^{15} \mathrm{NO}_{3}^{-}$due to upwelling of oxygen-depleted subsurface waters, which had undergone significant $\mathrm{NO}_{3}^{-}$-loss processes (mostly denitrification, but also anammox processes, associated with a high fractionation of up to 20-30\%o) (Lam et al., 2009; Altabet et al., 2012). Bulk sediment $\delta^{15} \mathrm{~N}_{\text {sed }}$ in areas with oxygen-depleted waters is therefore usually interpreted to reflect changes in the intensity of subsurface $\mathrm{NO}_{3}^{-}$reduction and the extent and strength of the oxygen minimum zone (Altabet et al., 1999; De Pol-Holz et al., 2007; Agnihotri et al., 2008; Gutiérrez et al., 2009). The direct comparison of $\delta^{30} \mathrm{Si}_{\text {opal }}$, reflecting mostly utilisation, and $\delta^{15} \mathrm{~N}_{\text {sed }}$, reflecting both utilisation and $\mathrm{NO}_{3}^{-}$reduction, from core B0405-6 off Pisco will therefore provide insights into the strength of $\mathrm{NO}_{3}^{-}$reduction in the past. 

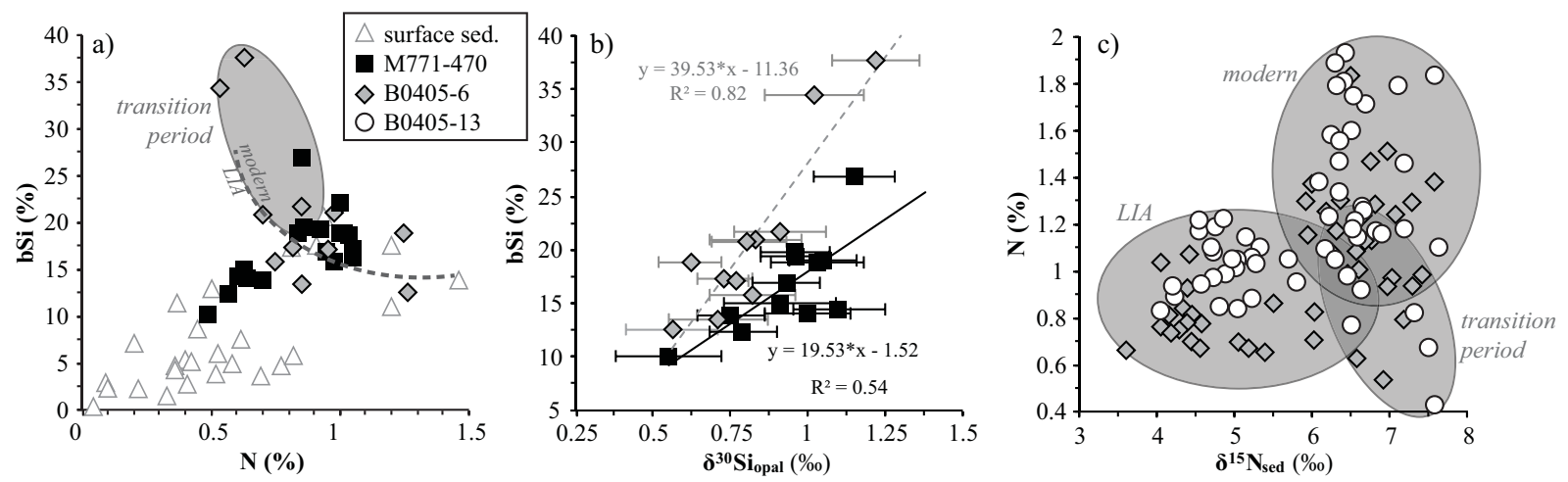

Figure 3. Surface sediment (white triangles) and downcore data (core M771-470: black squares; B0405-6: grey diamonds; B0405-13: white circles) for (a) total $\mathrm{N}$ versus bSi concentrations (the dashed line marks the end of the LIA), (b) $\delta^{30} \mathrm{Si}_{\text {opal }}$ versus bSi concentration and (c) $\delta^{15} \mathrm{~N}_{\text {sed }}$ versus total $\mathrm{N}$ concentrations. Error bars represent $2 \sigma_{(\mathrm{sd})}$ external reproducibilities.

Subsurface water column $\delta^{15} \mathrm{~N}_{\mathrm{NO}_{3}^{-}}$data from the presentday Peruvian shelf are isotopically very heavy, in particular along the southern shelf region between 10 and $17^{\circ} \mathrm{S}$, where values of up to $+25 \%$ are reached due to the increasing oxygen deficit and intensification of $\mathrm{NO}_{3}^{-}$-loss processes (Mollier-Vogel et al., 2012; Altabet et al., 2012). These isotopically enriched waters are upwelled along the shelf and represent the source for organic matter production in the surface waters. Therefore, it is expected that the deposited sedimentary organic matter reflects these enriched subsurface water signatures. However, the latitudinal increase in surface sediment $\delta^{15} \mathrm{~N}_{\text {sed }}$ from the same shelf region to maximum mean values around $+9 \%$ is much lower than that measured in the water column (Mollier-Vogel et al., 2012). The reason for this observation is that the $\delta^{15} \mathrm{~N}_{\text {sed }}$ signal in the southern shelf region $\left(10-17^{\circ} \mathrm{S}\right)$ did not fully record the ${ }^{15} \mathrm{NO}_{3}^{-}$enrichment in the water column but is a combination of the isotopic effects associated with subsurface $\mathrm{NO}_{3}^{-}$ loss and incomplete surface water $\mathrm{NO}_{3}^{-}$utilisation and water mass mixing. Direct comparison of $\delta^{30} \mathrm{Si}_{\text {opal }}$ and $\delta^{15} \mathrm{~N}_{\text {sed }}$ allows for the relative importance of these processes to be investigated and distinguished (Fig. 4a). Diatoms off Peru preferentially take up $\mathrm{Si}(\mathrm{OH})_{4}$ and $\mathrm{NO}_{3}^{-}$at a ratio of $\sim 1: 1$ or below (Brzezinski, 1985; Takeda, 1998; Hutchins et al., 2002). If utilisation were the only driving factor, the sedimentary $\delta^{30} \mathrm{Si}_{\text {opal }}$ and $\delta^{15} \mathrm{~N}_{\text {sed }}$ should all plot close to a line that reflects the enrichment during increasing utilisation, i.e. $1.1 \%$ for $\delta^{30} \mathrm{Si}_{\text {opal }}$ (De La Rocha et al., 1997) and $\sim 5 \%$ o for $\delta^{15} \mathrm{~N}$ (DeNiro and Epstein, 1981; Minagawa and Wada, 1984). Under the influence of denitrification with an enrichment of $\sim 20 \%$ o (Lam et al., 2009), however, the relationship between $\delta^{30} \mathrm{Si}_{\text {opal }}$ and $\delta^{15} \mathrm{~N}_{\text {sed }}$ would be very different (Fig. 4a).

Most modern shelf samples plot either on or above the theoretical curve for utilisation implying, if at all, $\mathrm{Si}(\mathrm{OH})_{4}$ limiting conditions (Fig. 4a). Very few samples are shifted towards the theoretical curve for denitrification, indicating a weak influence of $\mathrm{NO}_{3}^{-}$-loss processes on the preserved isotope signatures. Especially along the central shelf region (green curves in Fig. 4a), where the cores were sourced, surface sediment signatures closely reflect the utilisation in surface waters with only little influence of $\mathrm{NO}_{3}^{-}$loss in the water column and sediments.

\subsubsection{Past surface water utilisation versus subsurface nitrate loss}

Assuming that source water isotope composition $(+1.5 \%$ o $\delta^{30} \mathrm{Si}_{\mathrm{Si}(\mathrm{OH})_{4}},+9 \% \delta^{15} \mathrm{~N}_{\mathrm{NO}_{3}}$ ) and isotope enrichment during utilisation and denitrification (utilisation: $-1.1 \%$ for $\delta^{15}$ Siopal and $\sim-5 \%$ for $\delta^{15} \mathrm{NNO}_{3}^{-}$, denitrification: $-20 \%$ or for $\delta^{15} \mathrm{NNO}_{3}^{-}$) in the past were similar to the conditions of the present-day shelf region (Ehlert et al., 2012; Mollier-Vogel et al., 2012), the samples of core B0405-6 indicate variable utilisation/ $\mathrm{NO}_{3}^{-}$-loss conditions (Fig. $4 \mathrm{~b}$ ). Samples from the LIA and the transition period generally plot on or above the utilisation curve, indicating stronger $\mathrm{Si}(\mathrm{OH})_{4}$ than $\mathrm{NO}_{3}^{-}$utilisation. This implies that in the Peruvian upwelling system has rather been a $\mathrm{Si}(\mathrm{OH})_{4}$-limited system during that time, similar to today (Fig. 4a). During the transition period, when strong upwelling conditions caused intense blooming of Skeletonema costatum, utilisation of $\mathrm{Si}(\mathrm{OH})_{4}$ and $\mathrm{NO}_{3}^{-}$was very close to a $1: 1$ ratio. In contrast, the samples from the end of the LIA and especially the recent samples are shifted slightly towards the denitrification curve, indicating a higher influence of $\mathrm{NO}_{3}^{-}$-loss processes. This is particularly the case for the samples from the end of the LIA, which have the lowest $\delta^{30} \mathrm{Si}_{\text {opal }}$ but at the same time already show a strong increase in $\delta^{15} \mathrm{~N}_{\text {sed }}$ to values of near $+6 \%$. The most likely explanation is that upwelling was strongly increased during those brief periods, resulting in high nutrient supply, high productivity, and either more complete $\mathrm{NO}_{3}^{-}$utilisation (Gutiérrez et al., 2009) or increased $\mathrm{NO}_{3}^{-}$loss caused by enhanced subsurface oxygen 

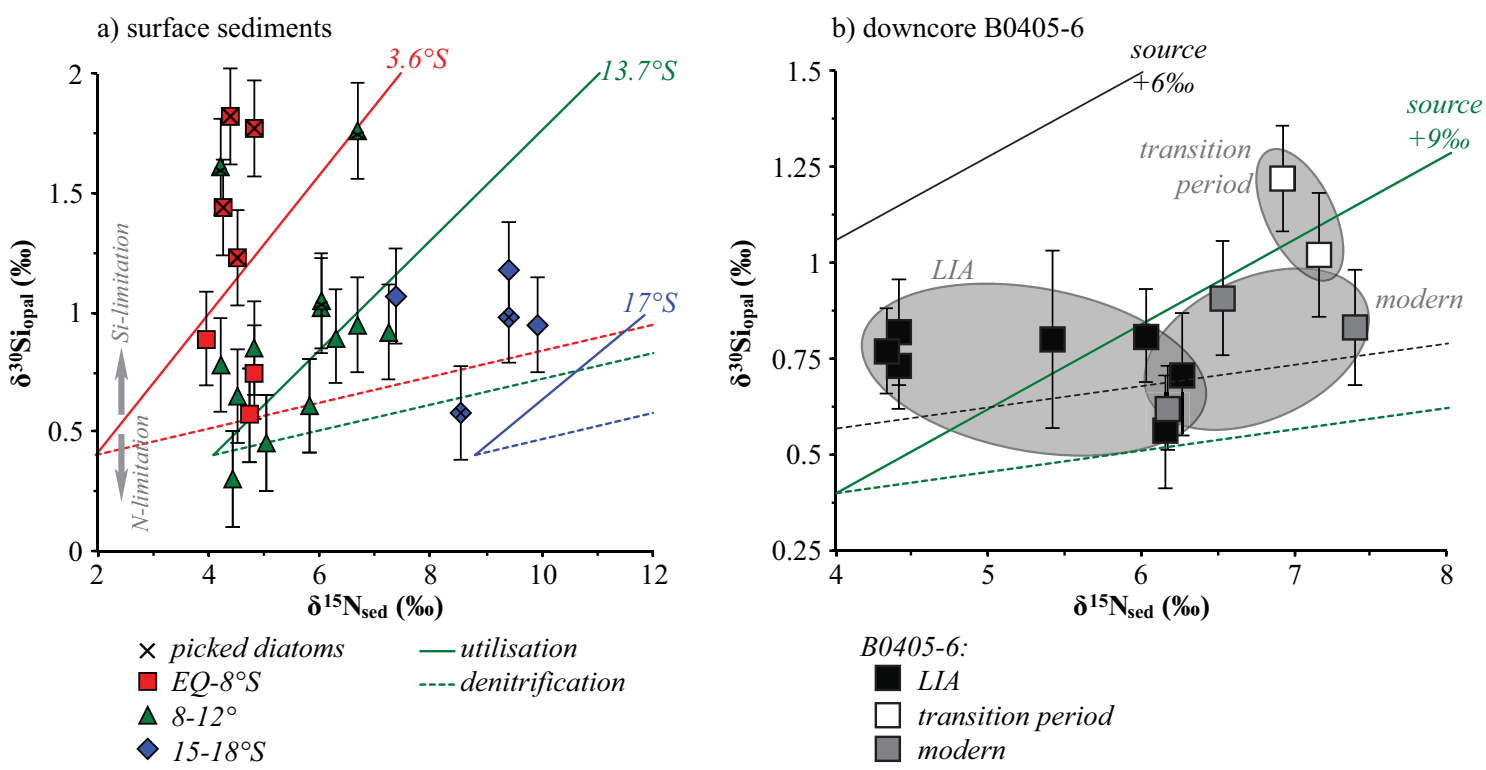

Figure 4. Relationship between $\delta^{15} \mathrm{~N}_{\text {sed }}$ versus $\delta^{30} \mathrm{Si}_{\text {opal }}$ for (a) surface sediments and (b) downcore data from core B0405-6. The crosses in (a) indicate $\delta^{30} \mathrm{Si}$ data obtained from hand-picked diatoms, which reflect a different growth season than bulk $\delta^{30} \mathrm{Si}_{\text {opal }}$ and which are influenced by stronger $\mathrm{Si}(\mathrm{OH})_{4}$ limitation (higher $\delta^{30} \mathrm{Si}$ ) (Ehlert et al., 2012). The solid lines reflect theoretical utilisation (assuming 1 : 1 utilisation of $\mathrm{Si}(\mathrm{OH})_{4}$ and $\mathrm{NO}_{3}^{-}$by the diatoms) and the dashed lines mark the theoretically expected line for denitrification, which represent the expected signal preserved in the sediments, based on present-day measurements: $\delta^{30} \mathrm{Si}$ source signature and enrichment factor $\varepsilon_{\text {diatom}-\mathrm{Si}(\mathrm{OH})_{4}}$ are always $+1.5 \%$ (Ehlert et al., 2012) and $-1.1 \%$ (De La Rocha et al., 1997), respectively. $\delta^{15} \mathrm{~N}_{\text {sed }}$ source signature and $\varepsilon_{\text {organic }}-\mathrm{NO}_{3}$ vary with latitude (Mollier-Vogel et al., 2012); in the north at $3.6^{\circ} \mathrm{S}$, source signature and $\varepsilon$ are +5.7 and $-3.7 \%$ (red curves); along the central shelf at $13.7^{\circ} \mathrm{S}$, source signature and $\varepsilon$ are +8.9 and $-4.8 \%$ (green curves); and in the south at $17^{\circ} \mathrm{S}$, source signature and $\varepsilon$ were measured to be +14.5 and $-5.7 \%$ (blue curves), respectively. The samples are colour-coded according to their location on the shelf and relative to the $\mathrm{NO}_{3}^{-}$utilisation/ $\mathrm{NO}_{3}^{-}$loss that they experienced. Data points that plot above the utilisation curves reflect predominant $\mathrm{Si}(\mathrm{OH})_{4}$ limitation, whereas data points below record stronger $\mathrm{NO}_{3}^{-}$limitation. The isotopic enrichment during denitrification was always set to be $+20 \%$. For the downcore data (b) two different assumed source signatures are displayed: $+9 \%$ (green lines, corresponding to the modern conditions along the central shelf region in a) and $+6 \%$ (grey lines). Data points are colour-coded according to the respective time periods (black: LIA; white: transition period; grey: modern). Error bars represent $2 \sigma_{(\mathrm{sd})}$ external reproducibilities.

depletion. Overall, however, the utilisation signal appears to have dominated both the $\mathrm{Si}$ and $\mathrm{N}$ isotope records.

If, however, the $\delta^{15} \mathrm{~N}_{\text {sed }}$ is dominated by utilisation it is interesting that $\delta^{15} \mathrm{~N}_{\text {sed }}$ and proxies for sediment redox conditions (e.g. molybdenum concentrations) in the cores (both B0405-6 and B0405-13) are strongly coupled throughout the record (Sifeddine et al., 2008; Gutiérrez et al., 2009). One direct interpretation could be that the diatom blooms, and subsequently the degradation of the organic matter, strongly control the oxygen availability in the sediments after sedimentation and burial. Therefore, increased diatom productivity and higher $\mathrm{Si}(\mathrm{OH})_{4}$ and $\mathrm{NO}_{3}^{-}$utilisation would result in an increase in $\delta^{15} \mathrm{~N}_{\text {sed }}$. At the same time, more oxygen is consumed during degradation of the organic matter in the sediments, causing more reducing conditions in the sediments. Consequently, a change in the subsurface water column structure, e.g. enhanced re-supply of oxygen via ocean currents, may not be reflected in the $\delta^{15} \mathrm{~N}_{\text {sed }}$ record.

\subsubsection{Modelling the surface water utilisation}

Following the above considerations we will try to quantify past utilisation based on our data. The theoretical relationship between the degree of surface water nutrient utilisation and the stable isotope composition of $\mathrm{Si}$ and $\mathrm{N}$ can be described assuming either Rayleigh-type (single input followed by no additional nutrients newly supplied to a particular parcel of water followed by fractional loss as a function of production and export) or steady-state (continuous supply and partial consumption of nutrients causing a dynamic equilibrium of the dissolved nutrient concentration and the product) fractionation behaviour (Fig. 5) (Mariotti et al., 1981). The lighter isotopes are preferentially incorporated into the diatom frustules and the organic matter, respectively, leaving the dissolved fraction enriched in the heavier isotopes (Wada and Hattori, 1978; Altabet et al., 1991; De La Rocha et al., 1997). The fractionation between $\delta^{30} \mathrm{Si}$ in seawater and $\delta^{30} \mathrm{Si}$ in the produced diatom opal has generally been assumed to be $-1.1 \%$ (De La Rocha et al., 1997), whereas between 

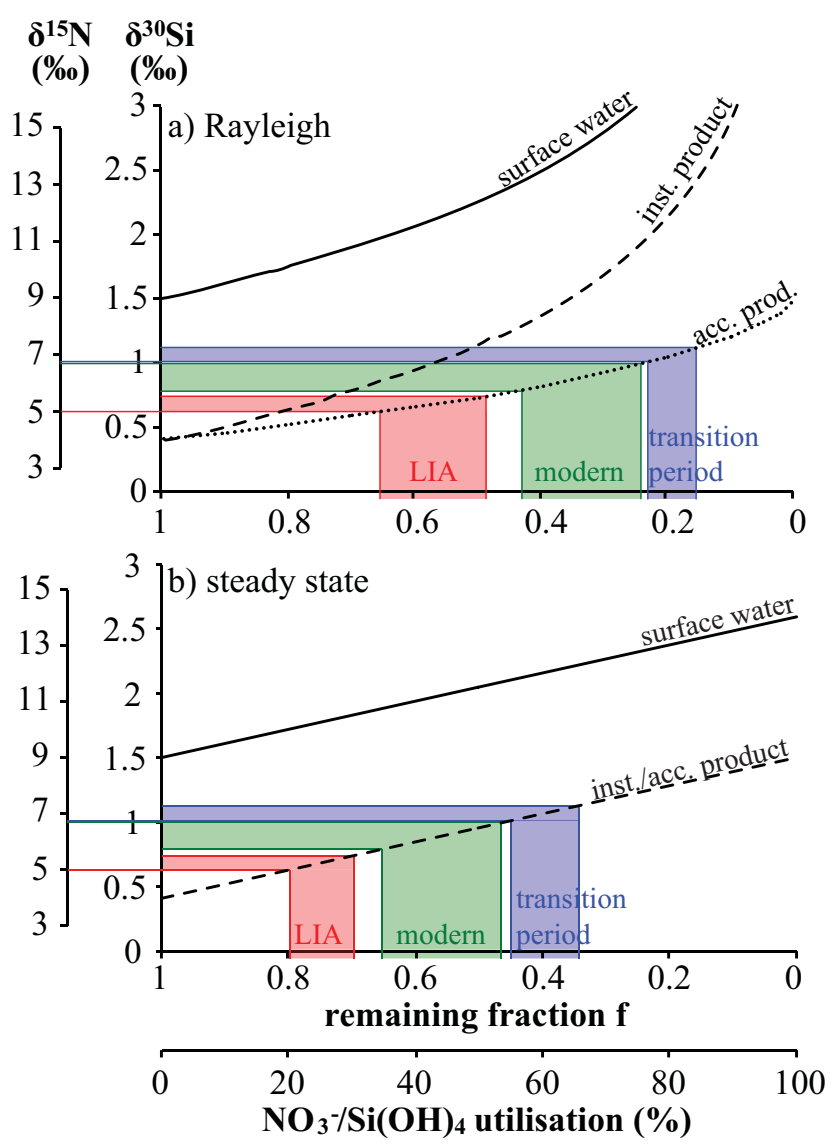

Figure 5. Theoretical changes in $\delta^{30} \mathrm{Si}$ and $\delta^{15} \mathrm{~N}$ values of seawater and the instantaneous and accumulated product as a function of $f$ (remaining nutrients from the available pool $=\left[\right.$ nutrient $\left._{\text {observed }}\right] /\left[\right.$ nutrient $\left._{\text {initial }}\right]$ ) with an initial $\delta^{30} \mathrm{Si}_{\mathrm{Si}(\mathrm{OH}) 4}$ value of $+1.5 \%$ and $\delta^{15} \mathrm{~N}_{\mathrm{NO}_{3}^{-}}$of $+9 \%$. The formation of the product, e.g. diatom opal, follows either (a) Rayleightype fractionation or (b) steady-state-type fractionation behaviour, with enrichment factors $\varepsilon$ of $-1.1 \% \circ\left(\delta^{30} \mathrm{Si}\right)$ and $-5 \% \circ\left(\delta^{15} \mathrm{~N}\right)(\mathrm{cor}-$ responding to conditions along the modern central Peruvian shelf; see Fig. 4). The colour shadings mark the range of measured mean $\delta^{30} \mathrm{Si}_{\text {opal }}$ (both cores) and $\delta^{15} \mathrm{~N}_{\text {sed }}$ (B0405-6 only) in the cores for the LIA (red), the transition period (blue) and modern sediments (green), from which the respective nutrient utilisation (\%) can be deduced.

$\delta^{15} \mathrm{~N}_{\mathrm{NO}_{3}^{-}}$of seawater and $\delta^{15} \mathrm{~N}$ of the newly formed organic matter it is usually between -3 and $-6 \%$ (DeNiro and Epstein, 1981; Minagawa and Wada, 1984). Here we adopted $-5 \%$, which corresponds to present-day conditions along the central Peruvian shelf (Mollier-Vogel et al., 2012).

Along the Peruvian shelf region biological productivity in the euphotic zone is mainly driven by upwelling of nutrients from subsurface waters. For the calculation of the utilisation of these nutrients, an initial $\delta^{30} \mathrm{Si}_{\mathrm{Si}(\mathrm{OH}) 4}$ of $+1.5 \%$ o (Ehlert et al., 2012) as well as an initial $\delta^{15} \mathrm{~N}_{\mathrm{NO}_{3}^{-}}$of $+9 \%$ 。 (Mollier-Vogel et al., 2012) for the upwelled water masses at $14^{\circ} \mathrm{S}$ is assumed. The lower mean $\delta^{15} \mathrm{~N}_{\text {sed }}$ of about $+5 \%$ and $\delta^{30} \mathrm{Si}_{\text {opal }}$ of $+0.7 \%$ o signatures during the LIA in the southerly core B0405-6 correspond to a dissolved $\delta^{15} \mathrm{~N}_{\mathrm{NO}_{3}^{-}}$and $\delta^{30} \mathrm{Si}_{\mathrm{Si}(\mathrm{OH}) 4}$ isotope signature of the surface waters of +10 and $+1.8 \%$ and a calculated $\mathrm{NO}_{3-}$ and $\mathrm{Si}(\mathrm{OH})_{4}$ utilisation of only $20-30 \%$ for steady-state-type fractionation (Fig. 5b) and 35-50\% for Rayleigh-type fractionation (Fig. 5a) behaviour. The highest mean values of $+1.1 \%$ o for $\delta^{30} \mathrm{Si}_{\text {opal }}$ and $+6.8 \%$ of $\delta^{15} \mathrm{~N}_{\text {sed }}$ for the transition period correspond to a much higher utilisation of $\sim 60 \%$ for steady-state-type fractionation and $\sim 80 \%$ assuming Rayleigh-type fractionation. Consequently, the calculated utilisation of available $\mathrm{Si}(\mathrm{OH})_{4}$ and $\mathrm{NO}_{3}^{-}$more than doubled, whereby bSi concentrations and diatom accumulation rates increased by about a factor of 3 (Fig. 2e).

The changes in $\mathrm{Si}(\mathrm{OH})_{4}$ and $\mathrm{NO}_{3}^{-}$utilisation were of the same order of magnitude and reflect low nutrient utilisation during the LIA and a much higher degree of utilisation thereafter. The large increase in $\delta^{15} \mathrm{~N}_{\text {sed }}$ at the end of the LIA has been interpreted to reflect an expansion of nutrientrich, oxygen-poor subsurface waters (Gutiérrez et al., 2009). However, comparison with $\delta^{30} \mathrm{Si}_{\text {opal }}$ shows that the increase in $\delta^{15} \mathrm{~N}_{\text {sed }}$ may indeed have occurred as a consequence of the extension of the oxygen minimum zone and increasing subsurface $\mathrm{NO}_{3}^{-}$loss but can also be explained by higher surface water utilisation. As Mollier-Vogel et al. (2012) have shown, the subsurface enrichment of $\delta^{15} \mathrm{~N}_{\mathrm{NO}_{3}^{-}}$caused by $\mathrm{NO}_{3}^{-}$-loss processes can only be reflected in the sediments under nearcomplete surface water $\mathrm{NO}_{3}^{-}$utilisation, which obviously did not occur at our studied sites.

In the modern samples the $\delta^{30} \mathrm{Si}_{\text {opal }}$ are characterised by a slight decrease after the transition period from mean value of +1.12 to $+0.82 \%$, whereas the $\delta^{15} \mathrm{~N}_{\text {sed }}$ values remain at the same level around $+7 \%$ (Fig. 2). This corresponds to a $\sim 20 \%$ higher $\mathrm{NO}_{3}^{-}$than $\mathrm{Si}(\mathrm{OH})_{4}$ utilisation (Fig. 5). However, when assuming that diatoms are the dominating primary producers with a $\mathrm{NO}_{3}^{-} / \mathrm{Si}(\mathrm{OH})_{4}$ uptake ration of $\sim 1$, these $20 \%$ could be interpreted to reflect the increase in subsurface $\mathrm{NO}_{3}^{-}$loss that is not observable during the LIA or the transition period; that is, during the LIA and the transition period utilisation was the dominating process influencing the $\delta^{15} \mathrm{~N}_{\text {sed }}$ signal, whereas during modern times $\mathrm{NO}_{3}^{-}$ loss enhanced the signal. By combining the $\delta^{30} \mathrm{Si}_{\text {opal }}$ and the $\delta^{15} \mathrm{~N}_{\text {sed }}$ records this "additional" signal can be quantified here: if only utilisation were to play a role, the expected $\delta^{15} \mathrm{~N}_{\text {sed }}$ signal would be $\sim+6 \%$ (corresponding to the measured $\sim+0.8 \%$ or for $\delta^{30} \mathrm{Si}_{\text {opal }}$, Fig. 5). The additional $1 \%$ o $\delta^{15} \mathrm{~N}_{\text {sed }}$ must be due to $\mathrm{NO}_{3}^{-}$loss.

The overall relatively low $\delta^{30} \mathrm{Si}_{\text {opal }}$ signatures between 0.8 and $1.0 \%$ during the LIA and in the modern part of the records (Figs. 2, 5) document that the utilisation of $\mathrm{Si}(\mathrm{OH})_{4}$ only changed slightly during the investigated period of time although the accumulation rate of produced diatoms was much higher after the LIA (Fig. 2e) (Gutiérrez et al., 2009). 

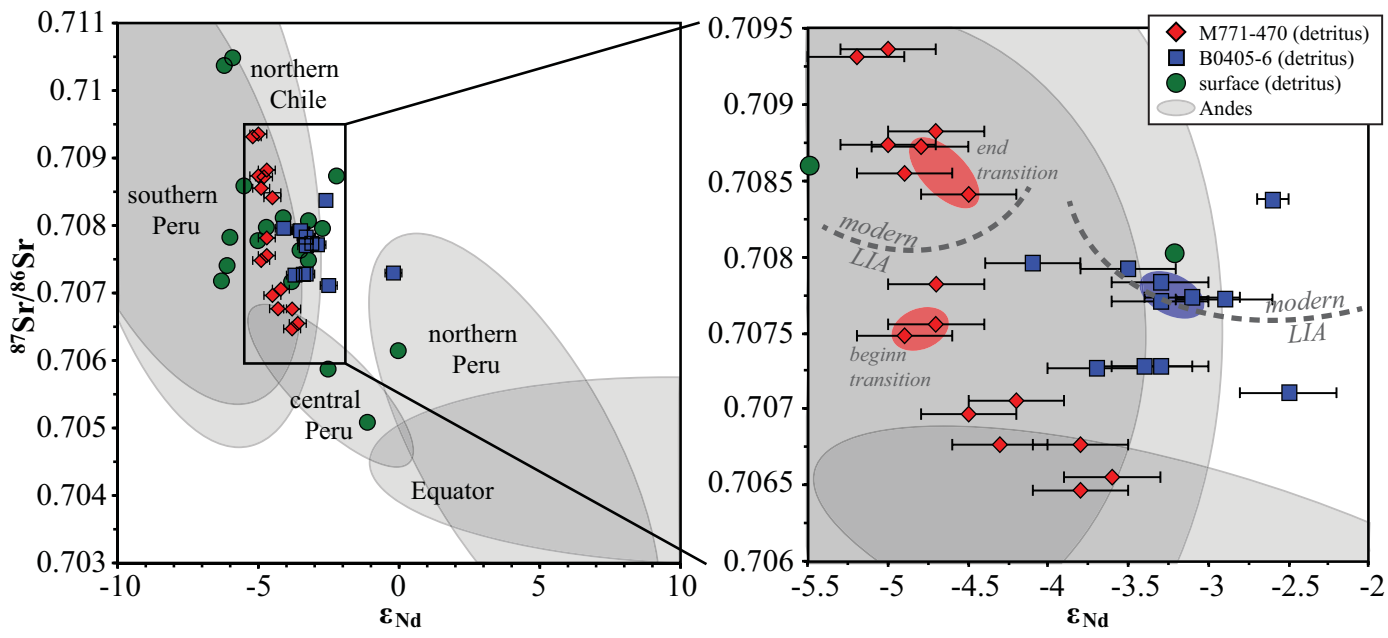

Figure 6. $\varepsilon_{\mathrm{Nd}}$ detritus versus ${ }^{87} \mathrm{Sr} /{ }^{86} \mathrm{Sr}_{\text {detritus }}$ for core M771-470 (red diamonds) and B0405-6 (blue squares). Error bars represent $2 \sigma_{(\mathrm{sd})}$ external reproducibilities. The green dots are data obtained from surface sediment samples at different sites on the Peruvian shelf. The grey shadings indicate potential sources and provenance end members of the detrital material.

This suggests that the nutrient concentrations in the upwelled subsurface source waters must have been lower during the LIA than they are today. During the LIA, large-scale circulation changes, i.e. a weak Walker circulation and a contraction of the SPSH (Conroy et al., 2008; Lamy et al., 2001), caused permanent El Niño-like conditions along the Peruvian upwelling system. During such conditions, the alongshore winds weakened and caused a deepening of the thermo-, oxyand nutricline, and therefore a reduction of vertical pumping of nutrient-rich and oxygen-depleted subsurface waters off Peru. Such a reduced nutrient supply to the euphotic zone from subsurface waters resulted in an increase in nutrient deficit in surface waters and decreased biological productivity. Enhanced water column oxygenation and lower organic matter flux led to decreased organic matter preservation in the sediments.

\subsubsection{Factors influencing the reconstruction of the utilisation signals}

There are two main factors that can influence the reconstruction of nutrient utilisation in the past: (1) a change in the dominating diatom assemblages has to be considered, and (2) the interpretation strongly depends on the assumptions for the environmental conditions, e.g. source water signature and isotope enrichment during utilisation.

Varying upwelling and nutrient supply conditions also cause changes in the dominating diatom assemblages. Recent results from culturing experiments suggest speciesdependent enrichment factors for diatom $\delta^{30} \mathrm{Si}(-0.5$ to $-2.1 \%$; Sutton et al., 2013) and also diatom frustulebound $\delta^{15} \mathrm{~N}(-1.9$ to $-11.2 \%$; Horn et al., 2011). This raises the question of whether a change in diatom assemblages may have been the cause of the observed downcore $\delta^{30} \mathrm{Si}_{\text {opal }}$ and, to a lesser extent, the bulk $\delta^{15} \mathrm{~N}_{\text {sed }}$ variations. The quasi-monospecific diatom layers from the transition period AD 1820-1870 consist mainly of Skeletonema costatum (Gutiérrez et al., 2009), for which an enrichment factor $\varepsilon$ of $-1.0 \%$, similar to the applied $-1.1 \%$, was determined (De la Rocha et al., 1997). The younger sediments also contain abundant upwelling-indicative species such as Thalassionema nitzschioides and Chaetoceros sp. (Abrantes et al., 2007), whereby Chaetoceros brevis, a species from the Southern Ocean, has been shown to have a much higher $\varepsilon$ of $-2.1 \%$ (Sutton et al., 2013). That means, assuming the same surface water $\delta^{30} \mathrm{Si}_{\mathrm{Si}(\mathrm{OH})_{4}}$ signatures, a dominance of Chaetoceros sp. in the sediments should result in a lower ${ }^{30} \mathrm{Si}_{\text {opal }}$, whereas assemblages dominated by Skeletonema costatum should be characterised by higher $\delta^{30} \mathrm{Si}_{\text {opal }}$ signatures, which is exactly what core B0405-6 shows. Consequently, the difference in $\delta^{30} \mathrm{Si}_{\text {opal }}$ over time could reflect the change in diatom assemblage and not a change in nutrient utilisation. On the other hand, Chaetoceros brevis is a polar species and it is not clear whether it undergoes the same high fractionation factor off Peru during frustule growth. It has been shown that the offset between modern surface water $\delta^{30} \mathrm{Si}_{\mathrm{Si}(\mathrm{OH}) 4}$ and surface sediment $\delta^{30} \mathrm{Si}_{\text {opal }}$ along the central Peruvian shelf is between -1.1 and $-1.3 \%$ (Ehlert et al., 2012), which indicates that either the enrichment factor for the dominating Chaetoceros species off Peru does not deviate significantly from $-1.1 \%$ or that the mixing of different diatoms in the sediment samples overprints any isotopic excursions of single species caused by higher or lower fractionation factors. Given the paucity of data on the fractionation factors for the dominant diatom species off Peru, the importance of the role of downcore changes in the assemblage composition is hard to determine. 
The assumed source water $\delta^{30} \mathrm{Si} \mathrm{Si}_{(\mathrm{OH}) 4}$ and $\delta^{15} \mathrm{~N}_{\mathrm{NO}_{3}^{-}}$values of +1.5 and $+9 \%$ (Figs. 5, 6), respectively, were measured in the present-day subsurface waters under strong upwelling conditions during which high amounts of nutrients are supplied to the euphotic zone (Ehlert et al., 2012; MollierVogel et al., 2012). Under strong upwelling conditions the bottom waters on the shallow shelf are today dominated by the southward-directed high-nutrient PCUC (Fig. 1) (Brink et al., 1983). Under LIA conditions (prevailing El Niño-like conditions), however, atmospheric and oceanic circulation was different; the nutricline was deeper as a consequence of a weak Walker circulation and the winds driving the upwelling were weaker as a consequence of the SPSH contraction (Salvatteci et al. 2014a). In fact, the pumped waters were likely nutrient-depleted, because the Ekman layer did not reach the subsurface nutrient-rich waters. Under these conditions, the subtropical and equatorial nutrient-depleted surface water masses may have occupied the entire surface layer in the coastal realm because they expanded both latitudinally and vertically in the water column (Montes et al., 2011). This may have changed the source water isotopic signatures and would therefore also change the calculated degrees of utilisation. If, for example, the assumed source water $\delta^{15} \mathrm{~N}_{\mathrm{NO}_{3}^{-}}$ was $+6 \%$ instead of $+9 \%$ (e.g. due to weaker subsurface $\mathrm{NO}_{3}^{-}$loss and weaker ${ }^{15} \mathrm{~N}$ enrichment during the LIA), the downcore $\delta^{15} \mathrm{~N}_{\text {sed }}$ data of core B0405-6 would all plot closer to the denitrification curve (Fig. $4 \mathrm{~b}$ ). Redox proxies from the records indeed indicate a weaker oxygen minimum zone (Gutiérrez et al., 2009), which would make a lower $\delta^{15} \mathrm{~N}_{\mathrm{NO}_{3}^{-}}$ in source waters likely. However, to date there is no reliable information regarding if and how much the source water $\delta^{30} \mathrm{Si}_{\mathrm{Si}(\mathrm{OH}) 4}$ and $\delta^{15} \mathrm{~N}_{\mathrm{NO}_{3}^{-}}$signatures changed over time.

In the following we thus investigate variations in past water mass circulation, upwelling conditions, and material input and transport to reconstruct the source water conditions without considering the potential influence of changes in diatom assemblages.

\subsection{Changes in water mass circulation, detrital material input and transport}

The radiogenic isotope composition of the lithogenic particles $\left(\varepsilon_{\mathrm{Nd} \text { detritus }}\right.$ and $\left.{ }^{87} \mathrm{Sr} /{ }^{86} \mathrm{Sr}_{\text {detritus }}\right)$ of the sediments provides useful information about the source region of material and therefore about changes in material input and transport, either aeolian or via ocean currents (e.g. Grousset et al., 1988). Surface sediments along the Peruvian shelf show highly variable signatures, which have overall more radiogenic $\varepsilon_{\mathrm{Nd}}$ detritus values in the north and much less radiogenic $\varepsilon_{\mathrm{Nd}}$ detritus values in the south off southern Peru and northern Chile (Ehlert et al., 2013). This north-south trend is a consequence of the southward increasing contributions of material input from the adjacent Andean hinterland rocks. The Andean rocks along the northwestern South American region display a wide range in $\varepsilon_{\mathrm{Nd}}$ and ${ }^{87} \mathrm{Sr} /{ }^{86} \mathrm{Sr}$ signatures (Fig. 6) (Sarbas and Nohl, 2009), varying from highly radiogenic $\varepsilon_{\mathrm{Nd}}$ around 0 and unradiogenic ${ }^{87} \mathrm{Sr} /{ }^{86} \mathrm{Sr}$ values around 0.704 in the equatorial region in northern Peru to much less radiogenic $\varepsilon_{\mathrm{Nd}}$ mostly below -4 and more radiogenic ${ }^{87} \mathrm{Sr} /{ }^{86} \mathrm{Sr}$ mostly above 0.705 in southern Peru and northern Chile. The sedimentary $\varepsilon_{\mathrm{Nd}}$ detritus and ${ }^{87} \mathrm{Sr} /{ }^{86} \mathrm{Sr}_{\text {detritus }}$ records of the two cores off Callao at $11^{\circ} \mathrm{S}$ and off Pisco at $14^{\circ} \mathrm{S}$ show broad similarities, but also some differences. Both cores recorded a significant change in $\varepsilon_{\mathrm{Nd}}$ detritus and ${ }^{87} \mathrm{Sr} /{ }^{86} \mathrm{Sr}_{\text {detritus }}$, and therefore a change in provenance, at the end of the LIA and during the transition period. Core M771470 , although from a location further north, is overall characterised by less radiogenic $\varepsilon_{\mathrm{Nd}}$ detritus values than core B04056 (Figs. 2, 6). The $\varepsilon_{\mathrm{Nd}}$ detritus of core M771-470 recorded a trend from less radiogenic towards more radiogenic values prior to the end of the LIA, followed by a step of 1.5 $\varepsilon_{\mathrm{Nd}}$ units towards less radiogenic values, which afterwards remained at that level. In contrast, the $\varepsilon_{\mathrm{Nd}}$ detritus record of core B0405-6 remained at a level around -3.6 during the LIA and then slightly increased to maximum values of up to -2.5 in the younger part. The ${ }^{87} \mathrm{Sr} /{ }^{86} \mathrm{Sr}_{\text {detritus }}$ record in both cores is mainly characterised by a rapid shift towards more radiogenic values at the end of the LIA, whereby the change was much more pronounced in core M771-470 (Figs. 2d, h). The youngest samples of the cores are in good agreement with measurements of surface sediments from the same area (Figs. 2, 6) (Ehlert et al., 2013). The variability in core M771470 displays the same magnitude as the complete glacialinterglacial variation in core SO147-106KL, from a location at $12^{\circ} \mathrm{S}$ off Lima (Ehlert et al., 2013). All data of both M771470 and B0405-6 plot within the provenance fields of southern Peru and northern Chile (Fig. 6).

Today, material input along the Peruvian shelf occurs mostly via riverine and minor aeolian input (Molina-Cruz, 1977; Scheidegger and Krissek, 1982). The LIA, however, was characterised by wetter conditions (Haug et al., 2001; Gutiérrez et al., 2009). These changes in precipitation were associated with the position of the ITCZ, changes in Walker circulation, and expansion/contraction of the SPSH (Salvatteci et al., 2014a). Additionally, there has been a tight connection to northern hemispheric climate. Speleothem records from the central Peruvian Andes, for example, indicate a pronounced link to North Atlantic climate (Kanner et al., 2013). During cold periods like the LIA, the Peruvian upwelling region exhibited an El Niño-like mean state (Salvatteci et al., 2014a) due to the mean southward migration of the ITCZ and the associated precipitation belt, which also caused more intense rainfall in the central Andean hinterland (Rabatel et al., 2008; Reuter et al., 2009). Most terrigenous particles and weathering products such as clay minerals from the LIA show indications of increased riverine transport and discharge (Sifeddine et al., 2008; Salvatteci et al., 2014a). Consequently, material input during the LIA was dominated by local sources due to the higher river discharge. 
After the end of the LIA the region experienced a northward displacement of the ITCZ and the northern rim of the SPSH to their modern position, coupled with an enhancement of the atmospheric Walker circulation (Gutiérrez et al., 2009). The climate in the EEP became drier and alongshore winds became stronger, riverine input diminished, and aeolian dust input increased. The wind-blown dust has mainly originated from the area of the Atacama Desert located in the southern Peruvian and northern Chilean Andes (MolinaCruz, 1977). This material has less radiogenic $\varepsilon_{\mathrm{Nd}}$ and much more radiogenic ${ }^{87} \mathrm{Sr} /{ }^{86} \mathrm{Sr}$ values (Fig. 6) (Sarbas and Nohl, 2009). The record of core M771-470 is in agreement with this. The LIA sediments indicate a local origin, probably via riverine input, whereas the younger sediments display characteristics from a more southerly origin and therefore increased aeolian sources, possibly from the Atacama Desert. The signatures and overall small variations in core B0405-6 are much more difficult to interpret. There are fewer rivers in southern Peru around Pisco compared to the Callao region. Therefore, riverine-derived material from northern and central Peru, which is transported via the PCUC, can get dispersed further south and can be deposited in the Pisco region. On the other hand, the influence of aeolian deposition should be much higher at the southern core location. During the LIA, river input increased in southern Peru as well, whereas aeolian deposition was low. The invariant signature observed might be the result of mixing of sediment from the different sources. Also, in comparison to core M771-470, core B04056 is from a location much closer to the coast, which most likely diminished the differences in material input and transport between the LIA and modern conditions.

In summary, our combined proxy information coherently hints at the same controlling processes that we have already identified on glacial-interglacial timescales (Ehlert et al., 2013) and at different El Niño-Southern Oscillation patterns during the LIA (enhanced El Niño-like conditions) and in modern times (La Niña-like conditions). The locally sourced radiogenic isotope signatures show that precipitation and runoff from the hinterland was higher during the LIA, but this could not compensate for the lower nutrient supply via diminished upwelling. Eolian wind forcing was low and the source waters of the upwelling carried less nutrients. Consequently, diatom productivity and nutrient utilisation were low. In contrast, after the end of the LIA, radiogenic isotopes indicate diminished river runoff and increased dust transport, which is in agreement with an overall drier climate, probably driven by an expansion of the SPSH, and a shoaling of the thermocline/nutricline due to a stronger atmospheric Walker circulation. Especially in more recent times, the efficient remineralisation of nutrients from subsurface waters fuelled enhanced diatom productivity most likely responsible for higher nutrient utilisation in surface waters as well as enhanced oxygen demand and $\mathrm{NO}_{3}^{-}$loss in subsurface waters.

\section{Conclusions}

Proxies of productivity, nutrient utilisation and material provenance (bSi and $\mathrm{N}$ content, $\delta^{30} \mathrm{Si}_{\mathrm{opal}}, \delta^{15} \mathrm{~N}_{\mathrm{sed}}, \varepsilon_{\mathrm{Nd}}$ detritus and ${ }^{87} \mathrm{Sr} /{ }^{86} \mathrm{Sr}_{\text {detritus }}$ ) from two cores from the Peruvian shelf recorded significant changes in surface water $\mathrm{Si}(\mathrm{OH})_{4}$ and $\mathrm{NO}_{3}^{-}$concentration and utilisation due to changes in upwelling intensity and nutrient supply. During the LIA the overall nutrient content in the water column and in surface waters was low because the upwelling source waters contained less nutrients. Consequently, the Peruvian upwelling regime was characterised by persistently reduced primary productivity. The reasons for this were most likely a contraction of the South Pacific subtropical high and a weaker Walker circulation that resulted in a weakening of alongshore winds and a deepening of the nutricline.

The enhanced rainfall associated with higher moisture on land during prevailing El Niño-like conditions during the LIA was recorded by the radiogenic isotope composition of the detrital material along the shelf, which was mainly transported via rivers from the Andean hinterland. At the end of the LIA, in accordance with a northward shift of the ITCZ and an intensification of wind strength, a higher dust transport of particles associated with drier conditions and aeolian forcing is reflected by the radiogenic isotope composition of the detrital sediments. These conditions were also reflected in increasing upwelling strength, a rapid shoaling of the thermocline and nutricline, and enhanced nutrient supply and productivity to the surface waters. During a transition period a marked increase in diatom blooming events doubled the $\mathrm{Si}(\mathrm{OH})_{4}$ and $\mathrm{NO}_{3}^{-}$utilisation compared to the LIA, and was also higher than present-day utilisation. After that transition period, more persistent non-El Niño conditions favoured a high productivity accompanied by moderate utilisation of nutrients. Utilisation was similar to the LIA but productivity was much higher, which reflects the much higher concentrations of nutrients in surface waters.

Most studies of past coastal upwelling regions have argued so far that the sedimentary $\delta^{15} \mathrm{~N}_{\text {sed }}$ records were dominated by the large $\mathrm{N}$ isotope fractionation signature occurring during $\mathrm{NO}_{3}^{-}$-loss processes (denitrification or anammox) in oxygen-depleted subsurface waters upwelling. However, comparison between $\delta^{30} \mathrm{Si}_{\text {opal }}$ and $\delta^{15} \mathrm{~N}_{\text {sed }}$ in the same sediment samples of our study, and assuming similar source water signatures to today, indicates that, except for the period of time since $\sim \mathrm{AD} 1870$, the $\delta^{15} \mathrm{~N}_{\text {sed }}$ signatures to a large extent reflect expected utilisation signals, which has important implications for the reconstruction of variations in the intensity of oxygen depletion, the $\mathrm{N}$ cycle of the past and its controlling factors.

The Supplement related to this article is available online at doi:10.5194/cp-11-187-2015-supplement. 
Acknowledgements. This work is a contribution of Sonderforschungsbereich 754 "Climate-Biogeochemistry Interactions in the Tropical Ocean" (www.sfb754.de), which is supported by the Deutsche Forschungsgemeinschaft. We acknowledge the help of Jutta Heinze in the laboratory of GEOMAR for the biogenic opal concentration measurements. We thank Ulrike Lomnitz and Klaus Wallmann for their help with the ${ }^{210} \mathrm{~Pb}$ dating and the establishment of the age model of core M771-470.

The service charges for this open access publication

have been covered by a Research Centre of the

Helmholtz Association.

Edited by: T. Kiefer

\section{References}

Abrantes, F., Lopes, C., Mix, A. C., and Pisias, N. G.: Diatoms in Southeast Pacific surface sediments reflect environmental properties, Quaternary Sci. Rev., 26, 155-169, 2007.

Agnihotri, R., Altabet, M. A., Herbert, T. D., and Tierney, J. E.: Subdecadally resolved paleoceanography of the Peru margin during the last two millennia, Geochem. Geophys. Geosys., 9, Q05013, doi:10.1029/2007GC001744, 2008.

Albarède, F., Telouk, P., Blichert-Toft, J., Boyet, M., Agranier, A., and Nelson, B.: Precise and accurate isotopic measurements using multiple-collector ICPMS, Geochim. Cosmochim. Ac., 68, 2725-2744, 2004.

Altabet, M. A. and Francois, R.: Sedimentary nitrogen isotopic ratio as a recorder for surface ocean nitrate utilisation, Global Biogeochem. Cy., 8, 103-116, 1994.

Altabet, M. A., Deuser, W. G., Honjo, S., and Stienen, C.: Seasonal and depth-related changes in the source of sinking particles in the North Atlantic, Nature, 354, 136-139, 1991.

Altabet, M. A., Pilskaln, C., Thunell, R. C., Pride, C. J., Sigman, D. M., Chavez, F. P., and Francois, R.: The nitrogen isotope biogeochemistry of sinking particles from the margin of the Eastern North Pacific, Deep-Sea Res. Pt. I, 46, 655-679, 1999.

Altabet, M. A., Ryabenko, E., Stramma, L., Wallace, D. W. R., Frank, M., Grasse, P., and Lavik, G.: An eddy-stimulated hotspot for fixed nitrogen-loss from the Peru oxygen minimum zone, Biogeosciences, 9, 4897-4908, doi:10.5194/bg-9-48972012, 2012.

Bird, B. W., Abbott, M. B., Vuille, M., Rodbell, D. T., Stansell, N. D., and Rosenmeier, M. F.: A 2,300-year-long annually resolved record of the South American summer monsoon from the Peruvian Andes, PNAS, 108, 8583-8588, 2011.

Brink, K. H., Halpern, D., Huyer, A., and Smith, R. L.: The Physical Environment of the Peruvian Upwelling System, Prog. Oceanogr., 12, 285-305, 1983.

Bruland, K. W., Rue, E. L., Smith, G. J., and DiTullio, G. R.: Iron, macronutrients and diatom blooms in the Peru upwelling regime: brown and blue waters of Peru, Mar. Chem., 93, 81-103, 2005.

Brzezinski, M. A.: The Si:C:N ratio of marine diatoms: interspecific variability and the effect of some environmental variables, Journal of Phycology, 21, 347-357, 1985.

Brzezinski, M. A., Pride, C. J., Franck, V. M., Sigman, D. M., Sarmiento, J. L., Matsumoto, K., Gruber, N., Rau, G. H., and
Coale, K. H.: A switch from $\mathrm{Si}(\mathrm{OH}) 4$ to NO3- depletion in the glacial Southern Ocean, Geophys. Res. Lett., 29, 3-6, 2002.

Codispoti, L. A., Brandes, J. A., Christensen, J. P., Devol, A. H., Naqvi, S. W. A., Paerl, H. W., and Yoshinary, T.: The oceanic fixed nitrogen and nitrous oxide budgets: Moving targets as we enter the anthropocene?, Sci. Mar., 65, 85-105, 2001.

Cohen, A. S., O'Nions, R. K., Siegenthaler, R., and Griffin, W. L.: Chronology of the pressure-temperature history recorded by a granulite terrain, Contribut. Mineral. Petrol., 98, 303-311, 1988.

Conroy, J. L., Restrepo, A., Overpeck, J. T., Steinitz-Kannan, M., Cole, J. E., Bush, M. B., and Colinvaux, P. A.: Unprecedented recent warming of surface temperatures in the eastern tropical Pacific Ocean, Nature Geosci., 2, 46-50, 2008.

Dalsgaard, T., Canfield, D. E., Petersen, J., Thamdrup, B., and Acuna-González, J.: N2 production by the anammox reaction in the anoxic water column of Golfo Dulce, Costa Rica, Nature, 422, 606-608, 2003.

De La Rocha, C. L., Brzezinski, M. A., and DeNiro, M. J.: Fractionation of silicon isotopes by marine diatoms during biogenic silica formation, Geochim. Cosmochim. Ac., 61, 5051-5056, 1997.

De La Rocha, C. L., Brzezinski, M. A., DeNiro, M. J., and Shemesh, A.: Silicon-isotope composition of diatoms as an indicator of past oceanic changes, Nature, 395, 680-683, 1998.

DeMaster, D. J.: The supply and accumulation of silica in the marine environment, Geochim. Cosmochim. Ac., 45, 1715-1732, 1981.

DeNiro, M. J. and Epstein, S.: Influence of diet on the distribution of nitrogen isotopes in animals, Geochim. Cosmochim. Ac., 45, 341-351, 1981.

De Pol-Holz, R., Ulloa, O., Dezileau, L., Kaiser, J., Lamy, F., and Hebbeln, D.: Melting of the Patagonian Ice Sheet and deglacial perturbations of the nitrogen cycle in the eastern South Pacific, Geophys. Res. Lett., 33, L04704, doi:10.1029/2005GL024477, 2006.

De Pol-Holz, R., Ulloa, O., Lamy, F., Dezileau, L., Sabatier, P., and Hebbeln, D.: Late Quaternary variability of sedimentary nitrogen isotopes in the eastern South Pacific Ocean, Paleoceanography, 22, PA2207, doi:10.1029/2006PA001308, 2007.

De Pol-Holz, R., Robinson, R. S., Hebbeln, D., Sigman, D. M., and Ulloa, O.: Controls on sedimentary nitrogen isotopes along the Chile margin, Deep-Sea Res. Pt. II, 56, 1042-1054, 2009.

De Souza, G. F., Reynolds, B. C., Rickli, J., Frank, M., Saito, M. A., Gerringa, L. J. A., and Bourdon, B.: Southern Ocean control of silicon stable isotope distribution in the deep Atlantic Ocean, Global Biogeochem. Cy., 26, GB2035, doi:10.1029/2011GB004141, 2012.

Díaz-Ochoa, J. A., Lange, C. B., Pantoja, S., De Lange, G. J., Gutiérrez, D., Munoz, P., and Salamanca, M.: Fish scales in sediments from off Callao, central Peru, Deep-Sea Res. Pt. II, 56, 1113-1124, 2009.

Díaz-Ochoa, J. A., Pantoja, S., De Lange, G. J., Lange, C. B., Sánchez, G. E., Acuña, V. R., Muñoz, P., and Vargas, G.: Oxygenation variability in Mejillones Bay, off northern Chile, during the last two centuries, Biogeosciences, 8, 137-146, doi:10.5194/bg-8-137-2011, 2011.

Egan, K. E., Rickaby, R. E. M., Leng, M. J., Hendry, K. R., Sloane, H. J., Bostock, H. C., and Halliday, A. N.: Diatom silicon isotopes as a proxy for silicic acid utilisation: A Southern Ocean 
core top calibration, Geochim. Cosmochim. Ac., 96, 174-192, 2012.

Ehlert, C., Grasse, P., Mollier-Vogel, E., Böschen, T., Franz, J., De Souza, G. F., Reynolds, B. C., Stramma, L., and Frank, M.: Factors controlling the silicon isotope distribution in waters and surface sediments of the Peruvian coastal upwelling, Geochim. Cosmochim. Ac., 99, 128-145, 2012.

Ehlert, C., Grasse, P., and Frank, M.: Changes in silicate utilisation and upwelling intensity off Peru since the Last Glacial Maximum - insights from silicon and neodymium isotopes, Quaternary Sci. Rev., 72, 18-35, 2013.

Estrada, M. and Blasco, D.: Phytoplankton assemblages in coastal upwelling areas, in: Simposio Internacional Sobre Las Areas de Afloramiento Mas Importantes del Oeste Africano (Cabo Blanco y Benguela), edited by: Bas, C., Margalef, R., and Rubies, P., Barcelona, Instituto de Investigaciones Pesqueras, 379402, 1985

Georg, R. B., Reynolds, B. C., Frank, M., and Halliday, A. N.: New sample preparation techniques for the determination of $\mathrm{Si}$ isotopic compositions using MC-ICPMS, Chem. Geol., 235, 95104, 2006.

Goldstein, S. L., O’Nions, R. K., and Hamilton, P. J.: A Sm-Nd isotopic study of atmospheric dusts and particulates from major river systems, Earth Planet. Sci. Lett., 70, 221-236, 1984.

Grasse, P., Stichel, T., Stumpf, R., Stramma, L., and Frank, M.: The distribution of neodymium isotopes and concentrations in the Eastern Equatorial Pacific: Water mass advection versus particle exchange, Earth Planet. Sci. Lett., 353/354, 198-207, 2012.

Grasse, P., Ehlert, C., and Frank, M.: The Influence of Water Mass Mixing on the Dissolved Si Isotope Composition in the Eastern Equatorial Pacific, Earth Planet. Sci. Lett., 380, 60-71, 2013.

Grousset, F. E., Biscaye, P. E., Zindler, A., Prospero, J., and Chester, R.: Neodymium isotopes as tracers in marine sediments and aerosols: North Atlantic, Earth Planet. Sci. Lett., 87, 367-378, 1988.

Grove, M. J.: The initiation of the "Little Ice Age" in regions round the North Atlantic, Clim. Change, 48, 53-82, 2001.

Gutiérrez, D., Sifeddine, A., Reyss, J.-L., Vargas, G., Velazco, F., Salvatteci, R., Ferreira-Bartrina, V., Ortlieb, L., Field, D. B., Baumgartner, T., Boussafir, M., Boucher, H., Valdés, J., Marinovic, L., Soler, P., and Tapia, P. M.: Anoxic sediments off Central Peru record interannual to multidecadal changes of climate and upwelling ecosystem during the last two centuries, Adv. Geosci., 6, 119-125, 2006,

http://www.adv-geosci.net/6/119/2006/.

Gutiérrez, D., Sifeddine, A., Field, D. B., Ortlieb, L., Vargas, G., Chavez, F. P., Velazco, F., Ferreira-Bartrina, V., Tapia, P. M., Salvatteci, R., Boucher, H., Morales, M. C., Valdés, J., Reyss, J.L., Campusano, A., Boussafir, M., Mandeng-Yogo, M., García, M., and Baumgartner, T.: Rapid reorganization in ocean biogeochemistry off Peru towards the end of the Little Ice Age, Biogeosciences, 6, 835-848, doi:10.5194/bg-6-835-2009, 2009.

Horn, M. G., Robinson, R. S., Rynearson, T. A., and Sigman, D. M.: Nitrogen isotopic relationship between diatom-bound and bulk organic matter of cultured polar diatoms, Paleoceanography, 26, PA3208, doi:10.1029/2010PA002080, 2011.

Horwitz, E. P., Chiarizia, R., and Dietz, M. L.: A Novel StrontiumSelective Extraction Chromatographic Resin, Solv. Extract. Ion Exch., 10, 313-336, 1992.
Hutchins, D. A., Hare, C. E., Weaver, R. S., Zhang, Y., Firme, G. F., DiTullio, G. R., Alm, M. B., Riseman, S. F., Maucher, J. M., Geesey, M. E., Trick, C. G., Smith, G. J., Rue, E. L., Conn, J., and Bruland, K. W.: Phytoplankton iron limitation in the Humboldt Current and Peru Upwelling, Limnol. Oceanogr., 47, 997-1011, 2002.

Kanner, L. C., Burns, S. J., Cheng, H., Edwards, R. L., and Vuille, M.: High-resolution variability of the South American summer monsoon over the last seven millennia: insights from a speleothem record from the central Peruvian Andes, Quaternary Sci. Rev., 75, 1-10, 2013.

Kessler, W. S.: The circulation of the eastern tropical Pacific: A review, Prog. Oceanogr., 69, 181-217, 2006.

Lacan, F. and Jeandel, C.: Tracing Papua New Guinea imprint on the central Equatorial Pacific Ocean using neodymium isotopic compositions and Rare Earth Element patterns, Earth Planet. Science Lett., 186, 497-512, 2001.

Lam, P., Lavik, G., Jensen, M. M., Van de Vossenberg, J., Schmid, M., Woebken, D., Gutiérrez, D., Amann, R., Jetten, M. S. M., and Kuypers, M. M. M.: Revising the nitrogen cycle in the Peruvian oxygen minimum zone, PNAS, 106, 4752-4757, 2009.

Lamb, H. H.: The early Medieval Warm Epoch and its sequel, Palaeogeography, Palaeoclimatology, Palaeoecology, 1, 13-37, 1965.

Lamy, F., Hebbeln, D., Röhl, U., and Wefer, G.: Holocene rainfall variability in southern Chile: a marine record of latitudinal shifts of the Southern Westerlies, Earth Planet. Science Lett., 185, 369382, 2001.

Liu, K.-K. and Kaplan, I. R.: The eastern tropical Pacific as a source of $15 \mathrm{~N}$-enriched nitrate in seawater off southern Califomia, Limnol. Oceanogr., 34, 820-830, 1989.

Mariotti, A., Germon, J. C., Hubert, P., Kaiser, P., Letolle, R., Tardieux, A., and Tardieux, P.: Experimental determination of nitrogen kinetic isotope fractionation: some principles; illustration for the denitrification and nitrification processes, Plant Soil, 62, 413-430, 1981.

Meysman, F. J. R., Boudreau, B. P., and Middelburg, J. J.: Modeling reactive transport in sediments subject to bioturbation and compaction, Geochim. Cosmochim. Ac., 69, 3601-3617, 2005.

Minagawa, M. and Wada, E.: Stepwise enrichment of $15 \mathrm{~N}$ along food chains: Further evidence and the relation between d15N and animal age, Geochim. Cosmochim. Ac., 48, 1135-1140, 1984.

Molina-Cruz, A.: The Relation of the Southern Trade Winds to Upwelling Processes during the Last 75,000 Years, Quaternary Res., 8, 324-338, 1977.

Mollier-Vogel, E., Ryabenko, E., Martinez, P., Wallace, D. W. R., Altabet, M. A., and Schneider, R. R.: Nitrogen isotope gradients off Peru and Ecuador related to upwelling, productivity, nutrient uptake and oxygen deficiency, Deep-Sea Res. Pt. I, 70, 14-25, 2012.

Montes, I., Schneider, W., Colas, F., Blanke, B., and Echevin, V.: Subsurface connections in the eastern tropical Pacific during La Niña 1999 - 2001 and El Niño 2002-2003, J. Geophys. Res., 116, C1202), doi:10.1029/2011JC007624, 2011.

Morley, D. W., Leng, M. J., Mackay, A. W., Sloane, H. J., Rioual, P., and Battarbee, R. W.: Cleaning of lake sediment samples for diatom oxygen isotope analysis, J. Paleilimno., 31, 391-401, 2004. 
Müller, P. J. and Schneider, R. R.: An automated leaching method for the determination of opal in sediments and particulate matter, Deep-Sea Res. Pt. I, 40, 425-444, 1993.

Piepgras, D. J. and Wasserburg, G. J.: Isotopic Composition of Neodymium in Waters from the Drake Passage, Science, 217, 207-214, 1982.

Rabatel, A., Francou, B., Jomelli, V., Naveau, P., and Grancher, D.: A chronology of the Little Ice Age in the tropical Andes of Bolivia $\left(16^{\circ} \mathrm{S}\right)$ and its implications for climate reconstruction, Quaternary Res., 70, 198-212, 2008.

Reuter, J., Stott, L., Khider, D., Sinha, A., Cheng, H., and Edwards, R. L.: A new perspective on the hydroclimate variability in northern South America during the Little Ice Age, Geophys. Res. Lett., 36, L21706, doi:10.1029/2009GL041051, 2009.

Reynolds, B. C., Aggarwal, J., André, L., Baxter, D. C., Beucher, C. P., Brzezinski, M. A., Engström, E., Georg, R. B., Land, M., Leng, M. J., Opfergelt, S., Rodushkin, I., Sloane, H. J., Van den Boorn, S. H. J. M., Vroon, P. Z., and Cardinal, D.: An interlaboratory comparison of $\mathrm{Si}$ isotope reference materials, J. Anal. Atom. Spectrom., 22, 561-568, doi:10.1039/b616755a, 2007.

Reynolds, B. C., Frank, M., and Halliday, A. N.: Evidence for a major change in silicon cycling in the subarctic North Pacific at 2.73 Ma, Paleoceanography, 23, PA4219, doi:10.1029/2007PA001563, 2008.

Sachs, J. P., Sachse, D., Smittenberg, R. H., Zhang, Z., Battisti, D. S., and Golubic, S.: Southward movement of the Pacific intertropical convergence zone AD 1400-1850, Nat. Geosci., 2, 519-525, 2009.

Salvatteci, R., Gutiérrez, D., Field, D. B., Sifeddine, A., Ortlieb, L., Bouloubassi, I., Boussafir, M., Boucher, H., and Cetin, F.: The response of the Peruvian Upwelling Ecosystem to centennial-scale global change during the last two millennia, Clim. Past, 10, 715731, doi:10.5194/cp-10-715-2014, 2014a.

Salvatteci, R., Field, D. B., Sifeddine, A., Ortlieb, L., FerreiraBartrina, V., Baumgartner, T., Caquineau, S., Velazco, F., Reyss, J.-L., Sanchez-Cabeza, J. A., and Gutiérrez, D.: Crossstratigraphies from a seismically active mud lens off Peru indicate horizontal extensions of laminae, missing sequences, and a need for multiple cores for high resolution records, Mar. Geol., 357, 72-89, 2014b.

Sarbas, B. and Nohl, U.: The GEOROC database - A decade of "online geochemistry", Geochim. Cosmochim. Ac., (Goldschmidt Abstracts), A1158, 2009.

Scheidegger, K. F. and Krissek, L. A.: Dispersal and deposition of eolian and fluvial sediments off Peru and northern Chile, Geol. Soc. Am. Bull., 93, 150-162, 1982.
Sifeddine, A., Gutiérrez, D., Ortlieb, L., Boucher, H., Velazco, F., Field, D. B., Vargas, G., Boussafir, M., Salvatteci, R., FerreiraBartrina, V., García, M., Valdés, J., Caquineau, S., MandengYogo, M., Cetin, F., Solis, J., Soler, P., and Baumgartner, T.: Laminated sediments from the central Peruvian continental slope: A 500 year record of upwelling system productivity, terrestrial runoff and redox conditions, Prog. Oceanogr., 79, 190-197, 2008.

Sutton, J. N., Varela, D. E., Brzezinski, M. A., and Beucher, C. P.: Species-dependent silicon isotope fractionation by marine diatoms, Geochim. Cosmochim. Ac., 104, 300-309, 2013.

Takeda, S.: Influence of iron availability on nutrient consumption ratio of diatoms in oceanic waters, Nature, 393, 774-777, 1998.

Tanaka, T., Togashi, S., Kamioka, H., Amakawa, H., Kagami, H., Hamamoto, T., Yuhara, M., Orihashi, Y., Yoneda, S., Shimizu, H., Kunimaru, T., Takahashi, K., Yanagi, T., Nakano, T., Fujimaki, H., Shinjo, R., Asahara, Y., Tanimizu, M., and Dragusanu, C.: JNdi-1: a neodymium isotopic reference in consistency with LaJolla neodymium, Chem. Geol., 168, 279-281, 2000.

Unkel, I., Kadereit, A., Mächtle, B., Eitel, B., Kromer, B., Wagner, G., and Wackler, L.: Dating methods and geomorphic evidence of palaeoenvironmental changes at the eastern margin of the South Peruvian coastal desert $\left(14^{\circ} 30^{\prime} \mathrm{S}\right)$ before and during the Little Ice Age, Quaternary Internat., 175, 3-28, 2007.

Valdés, J., Ortlieb, L., Gutiérrez, D., Marinovic, L., Vargas, G., and Sifeddine, A.: 250 years of sardine and anchovy scale deposition record in Mejillones Bay, northern Chile, Prog. Oceanogr., 79, 198-207, 2008.

Vargas, G., Pantoja, S., Rutllant, J. A., Lange, C. B., and Ortlieb, L.: Enhancement of coastal upwelling and interdecadal ENSOlike variability in the Peru-Chile Current since late 19th century, Geophys. Res. Lett., 34, L13607, doi:10.1029/2006GL028812, 2007.

Vuille, M., Francou, B., Wagnon, P., Juen, I., Kaser, G., Mark, B. G., and Bradley, R. S.: Climate change and tropical Andean glaciers: Past, present and future, Earth-Sci. Rev., 89, 79-96, 2008.

Wada, E. and Hattori, A.: Nitrogen isotope effects in the assimilation of inorganic nitrogenous compounds by marine diatoms, Geomicrobiol. J., 1, 85-101, 1978. 